\title{
Analgesic and Anticancer Activity of Benzoxazole Clubbed 2-Pyrrolidinones as Novel Inhibitors of Monoacylglycerol Lipase
}

\author{
Obaid Afzal ${ }^{1, *(D)}$, Abdulmalik Saleh Alfawaz Altamimi ${ }^{1, *}$, Mir Mohammad Shahroz ${ }^{2}$, Hemant Kumar Sharma ${ }^{2}$, \\ Yassine Riadi ${ }^{1}$ and Md Quamrul Hassan ${ }^{3}$ \\ 1 Department of Pharmaceutical Chemistry, College of Pharmacy, Prince Sattam Bin Abdulaziz University, \\ Al Kharj 11942, Saudi Arabia; y.riadi@psau.edu.sa \\ 2 Department of Pharmaceutical Chemistry, College of Pharmacy, Sri Satya Sai University of Technology and \\ Medical Sciences, Sehore 466001, Madhya Pradesh, India; mirshahroz@gmail.com (M.M.S.); \\ hkspharma@rediffmail.com (H.K.S.) \\ 3 Department of Pharmacology, School of Pharmaceutical Education and Research, Jamia Hamdard, \\ New Delhi 110062, India; quamrulhassan309@gmail.com \\ * Correspondence: o.akram@psau.edu.sa (O.A.); as.altamimi@psau.edu.sa (A.S.A.A.); \\ Tel.: +96-611-588-6094 (O.A.); +96-611-588-6072 (A.S.A.A.)
}

check for updates

Citation: Afzal, O.; Altamimi, A.S.A.; Shahroz, M.M.; Sharma, H.K.; Riadi,

Y.; Hassan, M.Q. Analgesic and

Anticancer Activity of Benzoxazole Clubbed 2-Pyrrolidinones as Novel Inhibitors of Monoacylglycerol Lipase. Molecules 2021, 26, 2389. https://doi.org/10.3390/ molecules 26082389

Academic Editor: Laura Micheli

Received: 20 March 2021

Accepted: 14 April 2021

Published: 20 April 2021

Publisher's Note: MDPI stays neutral with regard to jurisdictional claims in published maps and institutional affiliations.

Copyright: (c) 2021 by the authors. Licensee MDPI, Basel, Switzerland. This article is an open access article distributed under the terms and conditions of the Creative Commons Attribution (CC BY) license (https:// creativecommons.org/licenses/by/ $4.0 /)$.
Abstract: Ten benzoxazole clubbed 2-pyrrolidinones (11-20) as human monoacylglycerol lipase inhibitors were designed on the criteria fulfilling the structural requirements and on the basis of previously reported inhibitors. The designed, synthesized, and characterized compounds (11-20) were screened against monoacylglycerol lipase (MAGL) in order to find potential inhibitors. Compounds 19 (4- $\mathrm{NO}_{2}$ derivative) and $20\left(4-\mathrm{SO}_{2} \mathrm{NH}_{2}\right.$ derivative), with an $\mathrm{IC}_{50}$ value of 8.4 and $7.6 \mathrm{nM}$, were found most active, respectively. Both of them showed micromolar potency $\left(\mathrm{IC}_{50}\right.$ value above $50 \mu \mathrm{M})$ against a close analogue, fatty acid amide hydrolase (FAAH), therefore considered as selective inhibitors of MAGL. Molecular docking studies of compounds 19 and 20 revealed that carbonyl of 2-pyrrolidinone moiety sited at the oxyanion hole of catalytic site of the enzyme stabilized with three hydrogen bonds ( 2 $\AA$ ) with Ala51, Met123, and Ser122, the amino acid residues responsible for the catalytic function of the enzyme. Remarkably, the physiochemical and pharmacokinetic properties of compounds 19 and 20, computed by QikProp, were found to be in the qualifying range as per the proposed guideline for good orally bioactive CNS drugs. In formalin-induced nociception test, compound 20 reduced the pain response in acute and late stages in a dose-dependent manner. They significantly demonstrated the reduction in pain response, having better potency than the positive control gabapentin (GBP), at $30 \mathrm{mg} / \mathrm{kg}$ dose. Compounds 19 and 20 were submitted to NCI, USA, for anticancer activity screening. Compounds 19 (NSC: 778839) and 20 (NSC: 778842) were found to have good anticancer activity on SNB-75 cell line of CNS cancer, exhibiting 35.49 and 31.88\% growth inhibition (\% GI), respectively.

Keywords: analgesic; anticancer; pyrrolidin-2-one; benzoxazole; MAGL inhibitors; molecular docking

\section{Introduction}

Endocannabinoids (endogenous ligands), cannabinoid (CB) receptors, and proteins for their biological synthesis and degradation constitute the endocannabinoid system (ECS) [1]. Endocannabinoids are biosynthesized from the membrane phospholipids [2]. Endocannabinoid, $N$-arachidonoyl ethanolamine (AEA, Anandamide) functions as partial agonist on $\mathrm{CB}_{1}$ and $\mathrm{CB}_{2}$ receptors. It has low affinity for $\mathrm{CB}_{2}$ and moderate affinity for $\mathrm{CB}_{1}$. Endocannabinoids, 2-arachidonoylglycerol (2-AG) function as full agonist and have moderate affinity for both the receptors. Interestingly, 2-AG is the major endocannabinoid and is found to be approximately 170-fold higher in concentration than AEA, in the brain [3]. AEA and 2-AG hydrolysis and degradation are facilitated by fatty acid amide hydrolase 
(FAAH) and monoacylglycerol lipase (MAGL) enzymes, correspondingly [1]. MAGL (an $\alpha / \beta$-hydrolase) hydrolyzes 2-AG into glycerol and free fatty acid (FFA), by the action of the catalytic triad organized with Ser122, Asp239 and His269 amino acids in the active site of the enzyme [4]. MAGL hydrolyzes approximately $85 \%$ of total 2-AG in the CNS [5] and generates arachidonic acid (AA), giving rise to neuro-inflammatory $\mathrm{PGE}_{2}$ and $\mathrm{PGD}_{2}$ prostaglandins [6]. MAGL inhibitors ameliorates neuropathic pain by increasing 2-AG and decreasing neuro-inflammatory prostaglandins in the CNS (Figure 1) [7]. In addition, 2-AG demonstrated analgesic activity by acting on $\mathrm{CB}_{1}$ receptors in the $\mathrm{CNS}$ and periphery [8-11]. It is reported that JJKK-048 (MAGL, $\mathrm{IC}_{50} 363 \mathrm{pM}$ ) exhibited analgesic activity in tail immersion and writhing test [12]. MAGL inhibition has shown significant neuroprotective and anti-inflammatory potential in Parkinson's and Alzheimer's disease [13,14]. PF-06795071 $\left(\mathrm{IC}_{50} 3 \mathrm{nM}\right)$, a MAGL inhibitor, is reported to have considerable anti-neuroinflammatory potential [15]. Another MAGL inhibitor, ABX-1431 ( $\left.\mathrm{IC}_{50} 14 \mathrm{nM}\right)$ is under clinical trials for broad range of CNS disorders like Tourette syndrome [16]. Many more research findings encouraged that the inhibitors of MAGL has therapeutic potentials in pain and CNS disorders [17-20].

\section{A. PAIN}<smiles>CCCCCC/C=C\C=C/C=C\C=C/CCCC(=O)OC(CO)CO</smiles>

^ 2-Arachidonoylglycerol (2-AG)

\section{B. CANCER}<smiles>CCCCCCCCCCCC(=O)OCC(O)CO</smiles>

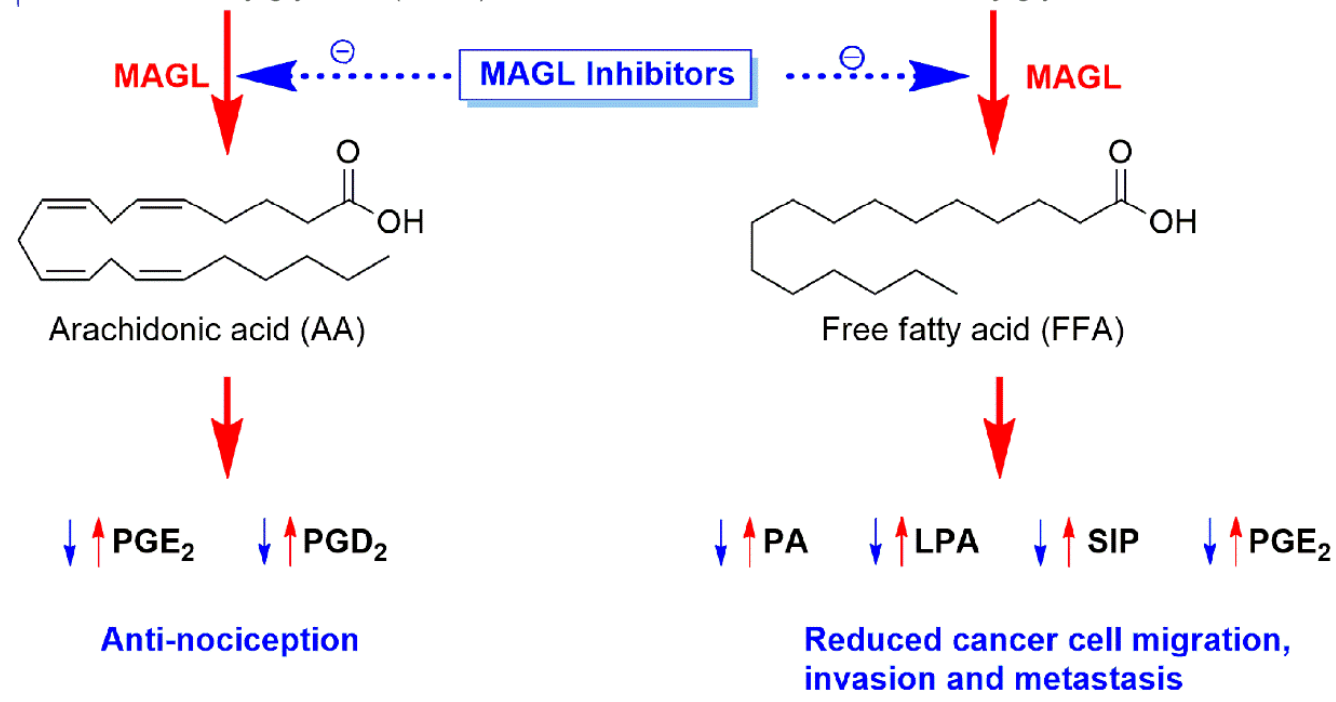

Figure 1. Role of MAGL inhibitors in the alleviation of pain and cancer. PG: prostaglandins; PA: phosphatidic acid; LPA: lysophosphatidic acid; and S1P: sphingosine-1-phosphate.

The governing importance of MAGL in abnormal lipolysis in cancer has been demonstrated [21]. MAGL was originally known for its lipolytic action on monoacylglycerols from stored triacylglycerols into glycerol and free fatty acids (FFA) [22]. Cancer cells utilizes this lipolytic pathways for their hastened proliferation [23]. The cancer-supporting action of MAGL is due to elevated FFA levels. This MAGL-FFA pathway promotes in vivo tumor growth by increasing FFA-derived oncogenic signaling lipids (PA, LPA, S1P, and $\mathrm{PGE}_{2}$ ) [18]. These protumorigenic lipid mediators encourage tumor growth, angiogenesis, and metastasis in cancer (Figure 1) [24]. MAGL is reported to expressed vastly in aggressive type of cancer cells and is associated with pathogenesis, proliferation, and in vivo tumor growth. MAGL inhibition disrupts cancer cell proliferation, growth and metastasis [25-27]. The anticancer effect of MAGL inhibition in prostate cancer was totally abolished by cotreat- 
ment with SR141716 (rimonabant; $\mathrm{CB}_{1}$ receptor antagonist) and fatty acids, signifying that amplified endocannabinoid action and reduced stock of FFA from MAGL inhibition is the reason behind antitumor effect [26].

MAGL inhibitors identified till date includes URB602 (IC $\left.{ }_{50} 28 \mu \mathrm{M}\right)$ [28], CAY10499 (IC $50144 \mathrm{nM}$ ) [29], SPB01403 (IC $5031 \mu \mathrm{M})$ [30], JZL184 (IC 50 nM) [31], SAR629 (IC 50 $1.1 \mathrm{nM})$ [32], KML29 (IC $503.6 \mathrm{nM}$ ) [33], ML30 (IC $500.54 \mathrm{nM}$ ) [34], JJKK-048 (IC 50363 pM) [35], ABX1431 (IC 5014 nM) [16], R(3t) (IC50 3.6 nM) [36], PF-06795071 (IC 503 nM) [15], a benzoylpiperidine derivative $\left(\mathrm{IC}_{50} 80 \mathrm{nM}\right)$ [37], and a benzisothiazolinone derivative $\left(\mathrm{IC}_{50}\right.$ $34.1 \mathrm{nM}$ ) [38]. JJKK-048 and KML29 both were reported to be highly selective MAGL inhibitors, and their selectivity is more than 10,000-fold over FAAH. [33,35]. In addition, 3D crystal structures of human MAGL enzyme were elucidated by X-ray crystallography, and are available on protein data bank $[32,36,39,40]$. A comprehensive description of MAGL crystal structures and inhibitors were reviewed [41]. Our group has also identified nanomolar MAGL inhibitors, viz. ZINC24092691 (IC 5010 nM), ZINC12863377 (IC 5039 nM), a ZINC24092691 analogue ( $\left.\mathrm{IC}_{50} 6.5 \mathrm{nM}\right)$, a thiazole-5-carboxylate derivative ( $\left.\mathrm{IC}_{50} 37 \mathrm{nM}\right)$, and a pyrrolidin-2-one linked benzimidazole derivative (compound 25; $\mathrm{IC}_{50} 9.4 \mathrm{nM}$ ) [42-45]. In continuation of our work on MAGL inhibitors, we have designed novel 2-pyrrolidinone linked benzoxazole derivatives and screened them for analgesic and anticancer effects.

\section{Results}

The binding pattern of pyrrolidin-2-one derivatives (ZINC12863377, compound 25 and compound R-3t), and the basic structural requirement for MAGL inhibitors was kept in mind to design novel pyrrolidin-2-one linked benzoxazole derivatives (Figure 2). The route of synthesis of compounds (11-20) is presented in Figure 3.

\subsection{Chemistry}

Intermediate compound 1, (1-Benzyl-5-oxopyrrolidine-3-carboxylic acid), was successfully prepared by fusion of benzylamine and methylidenesuccinic acid in water, while compounds 2-10 were synthesized as reported by us in our previous publication [45]. The fusion of synthesized 1-substituted-5-oxopyrrolidine-3-carboxylic acids (1-10) with 2-aminophenol was done by the procedure reported earlier with some minor modifications [46]. The fusion of acids (1-10) and 2-aminophenol was carried out by the use of polyphosphoric acid, giving better yields (57-70\%) and purity of benzoxazole derivatives (11-20).

The prototype intermediate compound 1, (1-Benzyl-5-oxopyrrolidine-3-carboxylic acid), revealed typical peaks at $1627 \mathrm{~cm}^{-1}$ (carbonyl of acid), $1734 \mathrm{~cm}^{-1}$ (carbonyl of pyrrolidinone), and $3241 \mathrm{~cm}^{-1}$ (O-H of acid) in IR spectrum. In ${ }^{1} \mathrm{H}-\mathrm{NMR}$ spectrum of compound $\mathbf{1}$, two methyl protons were found resonating as singlet at $\delta$ 3.62. The multiplets resonating at $\delta 2.62-2.76$ indicated two $\mathrm{COCH}_{2}$ protons, and at $\delta 4.29-4.44$ they indicated two $\mathrm{NCH}_{2}$ and one $\mathrm{CH}$ proton of 2-pyrrolidinone ring. Five aromatic protons of the benzyl ring were found resonating at $\delta 7.20-7.36$ as a multiplet. The typical singlet was assigned to $\mathrm{COOH}$ proton at $\delta 11.35$ and was found to be $\mathrm{D}_{2} \mathrm{O}$ exchangeable. Final prototype compound 11 (4-(Benzo[d]oxazol-2-yl)-1-benzylpyrrolidin-2-one) exhibited specific IR bands at $1621 \mathrm{~cm}^{-1}\left(\mathrm{C}=\mathrm{N}\right.$ of benzoxazole) and $1703 \mathrm{~cm}^{-1}$ ( $\mathrm{C}=\mathrm{O}$ of pyrrolidin-2-one). The two protons of $\mathrm{CH}_{2}$ of benzyl appeared at $\delta 3.95-4.01$ as a multiplet. Two $\mathrm{COCH}_{2}$ protons of the 2-pyrrolidinone ring was assigned at $\delta 2.60-2.77$ as a multiplet. The multiplets located at $\delta 3.13-3.18$ and 3.81-3.86 were ascribed to one $\mathrm{CH}$ proton and two $\mathrm{NCH}_{2}$ protons of the 2-pyrrolidinone ring, correspondingly. Six aromatic protons were found resonating at $\delta$ $7.38-7.58$ as a multiplet. The doublet resonating at $\delta 7.73-7.78$ was assigned to the aromatic protons of benzoxazole. The other two protons of benzoxazole were found resonating at $\delta$ 7.94-7.96 as doublet. The $\mathrm{M}^{+}$(molecular ion) peak of compound $\mathbf{1 1}$ was found at 292.14, validating its successful synthesis. 


\section{[A]. Pyrrolidin-2-one containing MAGL inhibitors}

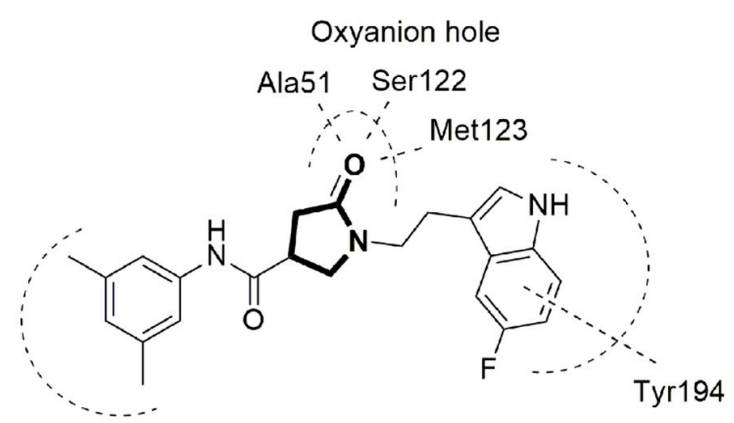

Hydrophobic void

$$
\begin{aligned}
& \text { ZINC12863377 } \\
& I_{50}=39 \mathrm{nM}
\end{aligned}
$$

Amphiphilic pouch

Ref.: Afzal, O. et. al, Bioorg. Med.Chem. Lett., 2014, 24, 3986-3996.

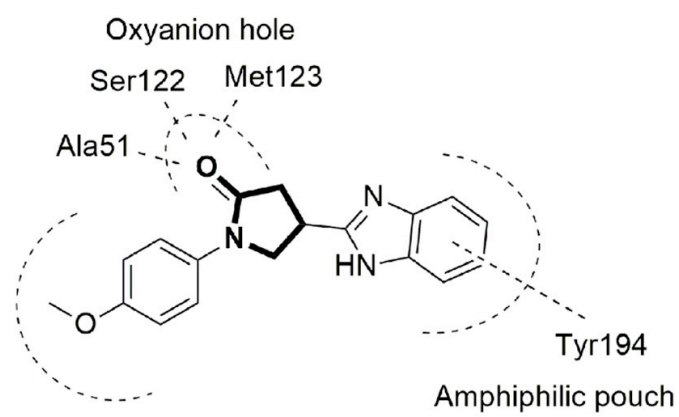

Hydrophobic void

Compound 25 Ref.: Afzal, O. et. al, $I_{50}=9.4 \mathrm{nM} \quad$ Chem. Biol. Drug Des

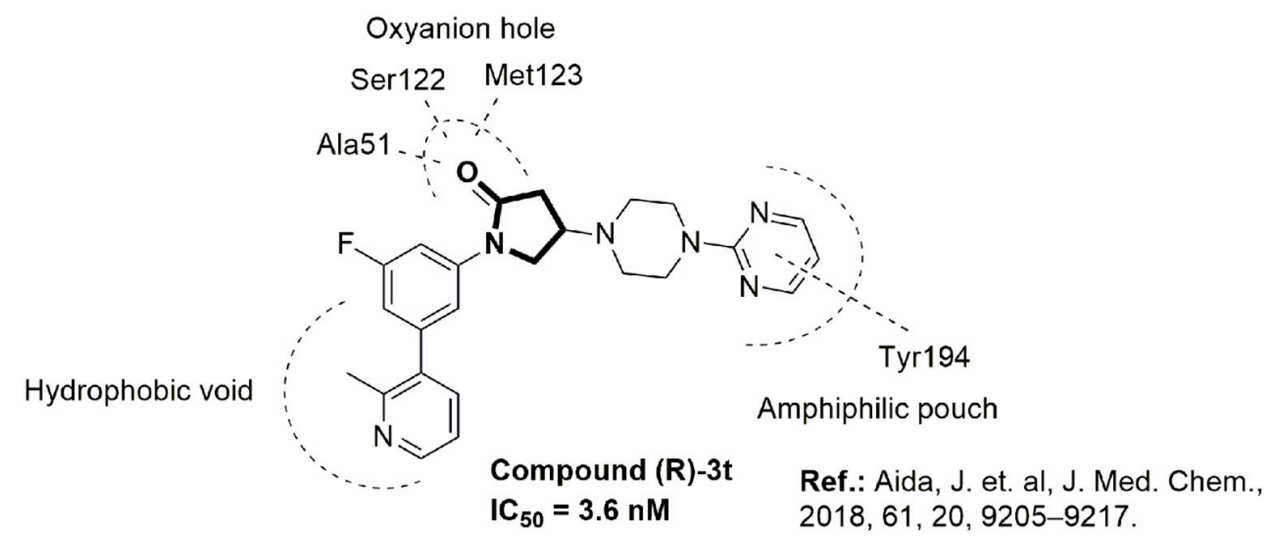

[B]. Designed pyrrolidin-2-one linked benzoxazole derivatives

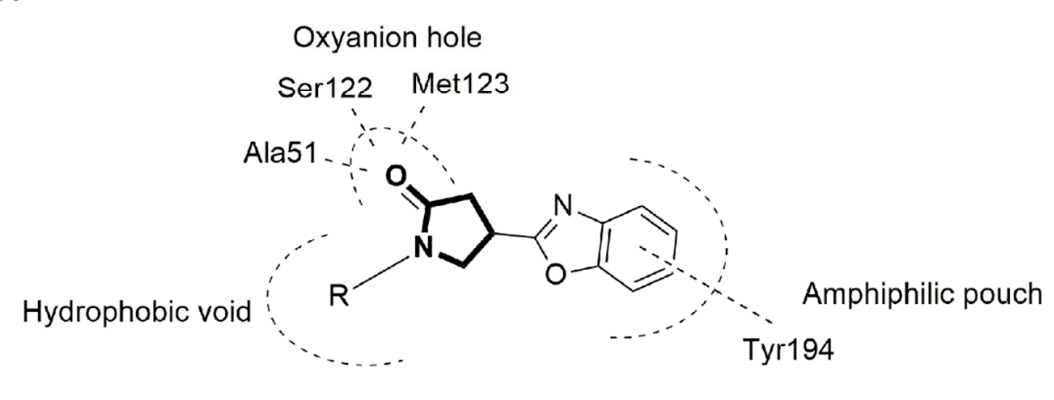

$\mathrm{R}=$ Aromatic substituents

Designed compounds (11-20)

Figure 2. Design of novel pyrrolidin-2-one linked benzoxazole MAGL inhibitors. (A) Binding pattern of reported pyrrolidin2-one MAGL inhibitors; ZINC12863377 [42], compound 25 [45] and (R)-3t [36]. (B) Designed compounds (11-20).

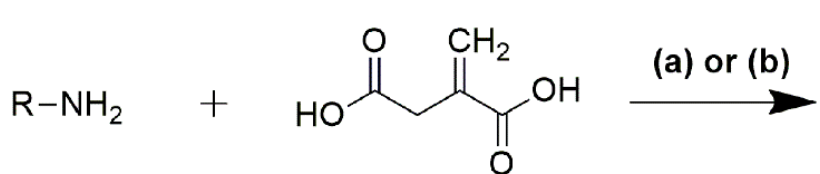

Aromatic amines

Itaconic acid<smiles>[R]N1CC(C(=O)O)CC1=O</smiles>

(1-10)

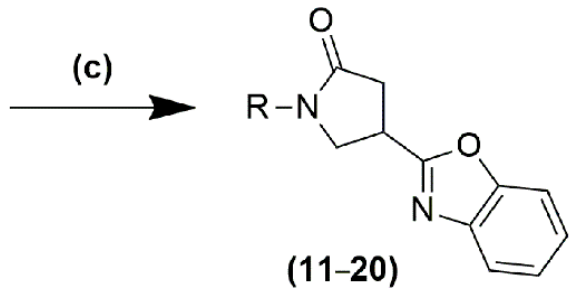

Figure 3. Scheme for synthesis of the intermediates (1-10) and target compounds (11-20). (a) Reflux in water (Method 1); (b) Fusion at $130-140{ }^{\circ} \mathrm{C}\left(\right.$ Method 2); (c) 2-aminophenol, polyphosphoric acid, $150-160{ }^{\circ} \mathrm{C}$, sodium carbonate. 


\subsection{Human MAGL Assay}

The assay was executed by Cayman's assay kit by the reported procedure [29]. All the ten compounds (11-20) were screened for $h$ MAGL inhibitory potential. The substituted phenyl derivatives (13-20) were established to reduce the MAGL activity at $100 \mu \mathrm{M}$ concentration below $50 \%$. Compound 19 (4- $\mathrm{NO}_{2}$ derivative) and compound $20\left(4-\mathrm{SO}_{2} \mathrm{NH}_{2}\right.$ derivative) were the most potent, with an $\mathrm{IC}_{50}$ of 8.4 and $7.6 \mathrm{nM}$, correspondingly. The structure-function relationship of benzoxazole derivatives is displayed $h$ MAGL inhibitory activity as follows: $4-\mathrm{SO}_{2} \mathrm{NH}_{2}>4-\mathrm{NO}_{2}>3-\mathrm{Cl}, 4-\mathrm{F}>4-\mathrm{OCH}_{3}>4-\mathrm{Cl}>4-\mathrm{OH}>4-\mathrm{CH}_{3}>2-$ $\mathrm{CH}_{3}>$ phenyl/benzyl. The $\mathrm{IC}_{50}$ of standard controls, selective MAGL inhibitors, CAY10499 $\left(\mathrm{IC}_{50}=415 \mathrm{nM}\right)$, and for JZL184 $\left(\mathrm{IC}_{50}=10 \mathrm{nM}\right)$ were comparable to the reported values [29]. The outcomes of the experiments are presented in Table 1.

Table 1. In vitro $h$ MAGL and $h$ FAAH inhibition assay of the synthesized compounds (11-20).

Compound

ND: Not determined; CAY10499, JZL184 and URB597 (standard control); $\mathrm{IC}_{50}$ values were calculated from GraphPad Prism (ver. 8.0.2). Results are expressed as mean $\pm \operatorname{SEM}(n=3)$. 


\subsection{Human FAAH Assay}

Derivatives having $\mathrm{IC}_{50}$ in nanomolar range (compound $15,16,18,19$, and 20 ) were nominated for further screening against FAAH, an allied hydrolase of MAGL [47]. They displayed micromolar potency, with an $\mathrm{IC}_{50}$ value ranging from 25 to $68 \mu \mathrm{M}$ against $\mathrm{FAAH}$. The benzoxazole derivatives having $4-\mathrm{NO}_{2}$ phenyl (19) and 4- $\mathrm{SO}_{2} \mathrm{NH}_{2}$ phenyl (20), with an FAAH IC 50 value greater than $50 \mu \mathrm{M}$, were considered selective MAGL inhibitors. The $\mathrm{IC}_{50}$ of standard control, URB597 (selective FAAH inhibitor), was $5 \mathrm{nM}$, equivalent to the value reported $\left(\mathrm{IC}_{50}=4.6 \mathrm{nM}\right)$ [48]. The outcomes of the experiments are presented in Table 1.

\subsection{Molecular Docking Study}

Most active and selective compounds identified by MAGL and FAAH inhibition assay (19 and 20), were docked at the catalytic center of MAGL, in order to get an insight of their binding pattern, with the help of XP Glide docking using Maestro (Schrodinger). Compounds 19 and 20, showed comparable docking scores of -9.87 and -9.83 , respectively. The binding of compounds $\mathbf{1 9}$ and $\mathbf{2 0}$ in the active site of MAGL revealed that the carbonyl group of pyrrolidinone is located exactly in the oxyanion hole and stabilized by three hydrogen bonds $(\sim 2 \AA)$ with alanine 51 , serine 122 , and methionine 123 . Serine 122 is one of the critical amino acid residues of the catalytic triad of MAGL. The benzoxazole moiety is found to be positioned in the amphiphilic pouch, having $\pi-\pi$ stacking contact with the amino acid Tyr194. The 4- $\mathrm{NO}_{2}(19)$ and $4-\mathrm{SO}_{2} \mathrm{NH}_{2}(20)$ phenyl ring of the ligands were involved in hydrophobic (van der Waals) attractions with the amino acids, leucine 148, 213, and 241. In addition, the 3D and 2D binding pattern of compounds 19 and 20 in the catalytic location of MAGL is depicted in Figure 4.

A.
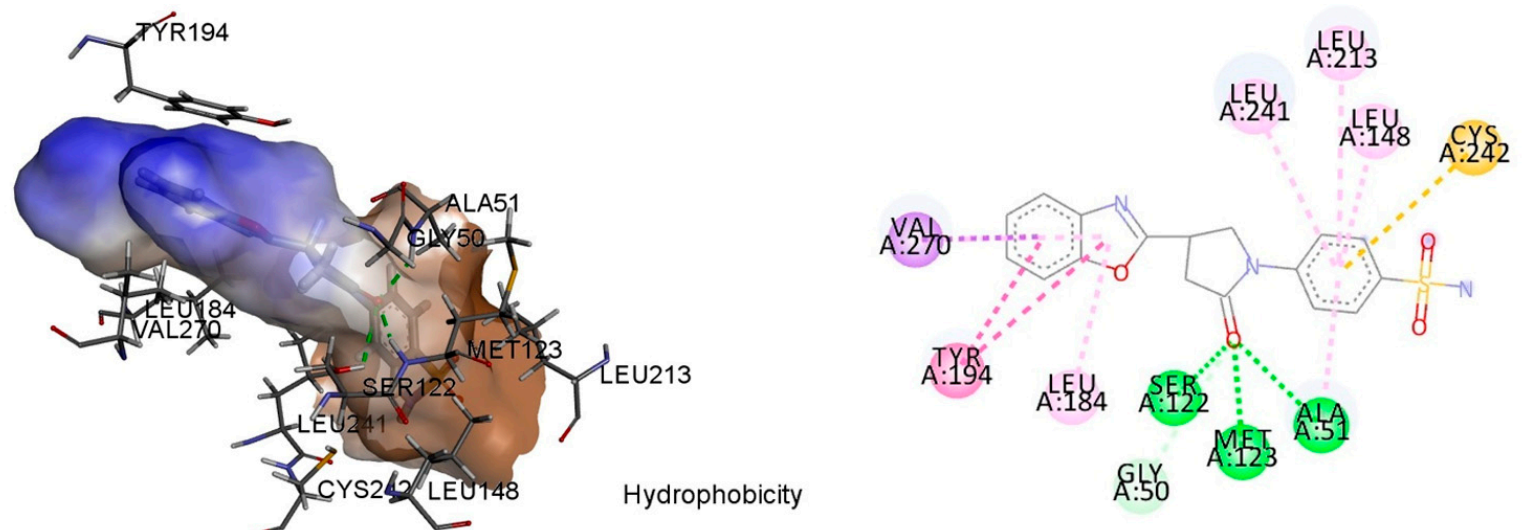

B.
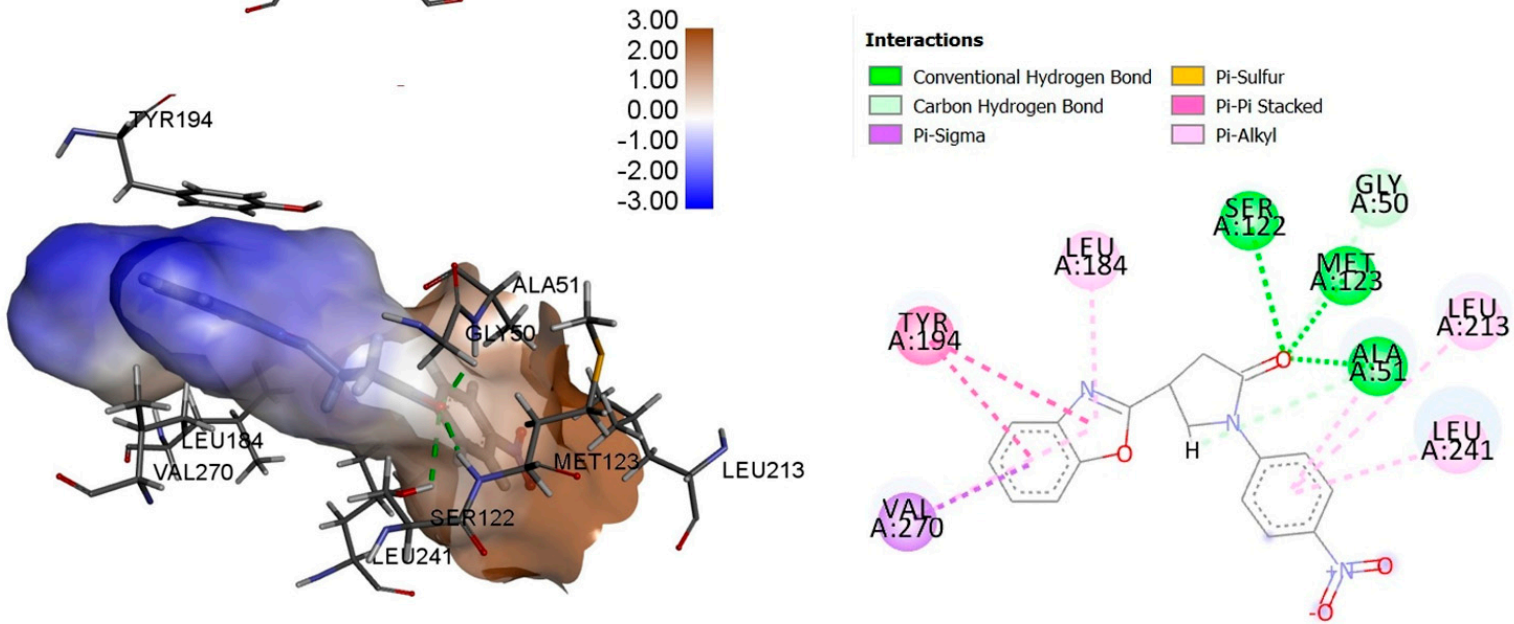

Figure 4. Glide XP docking; 3D and 2D representation of the binding pattern of compound 19 (A), and 20 (B) in the catalytic site of MAGL. The picture (2D and 3D) for the docked complexes were obtained from Discovery studio visualizer 2020. The hydrophobicity was calculated from the default option available. 


\subsection{Pharmacokinetic and Physicochemical Characteristics}

To investigate the potential of the identified derivatives (19 and 20) to cross the selectively permeable membranes of hematoencephalic barrier (BBB), to develop orally active CNS drugs, their pharmacokinetic and physicochemical features were computed by QikProp (ADMET predictor) of Schrodinger. Guidelines, concerning the validation and optimization of orally active CNS compounds, were developed by Ghose et. al., by analyzing 35 characteristic features of orally bioavailable 317 CNS and 626 non-CNS drugs [49]. This guideline states that in order to design high-quality CNS drugs, the molecule must qualify by the following parameters: TPSA less than $76 \AA^{2}$ (ideally $25-60 \AA^{2}$ ), number of $\mathrm{N}$ atoms between $1-2$, comprising 1 aliphatic amine, $2-4$ side chains on/outside rings, number of polar $\mathrm{H}$ atoms $<3$ (ideally 0-1), SASA 460-580 $\AA^{2}$, molecular volume 740-970 $\AA^{3}$, and must have +ve QikProp CNS property. Remarkably, most of the properties of compounds 19 and 20, computed by QikProp, were found to be in the qualifying range as per the proposed guideline (Table 2). The properties of compound 19 were found to be within the qualifying range except dipole moment. For compound 20, 5 out of 35 properties is just slightly above the upper qualifying limit. Most importantly, qualifying limits for CNS active drugs in terms of TPSA is from 3.8 to 109, and the calculated TPSA for compound 20 was found to be 119.08. Therefore, the designing of more potent MAGL inhibitors having physicochemical and pharmacokinetic properties within the preferred CNS limits is required.

Table 2. Physicochemical and pharmacokinetic properties of compounds 19 and 20, predicted by QikProp, Schrodinger, for CNS activity.

\begin{tabular}{|c|c|c|c|c|c|c|c|c|}
\hline \multirow{2}{*}{ S. No. } & \multirow{2}{*}{ Property } & \multirow{2}{*}{ Description } & \multicolumn{4}{|c|}{ Range of Properties in CNS Drugs } & \multirow{2}{*}{ Compound 19} & \multirow{2}{*}{ Compound 20} \\
\hline & & & QL & PL & PU & QU & & \\
\hline 1 & \#stars & $\begin{array}{l}\text { drug likeness penalty; the } \\
\text { higher the value, the less } \\
\text { drug-like the molecule }\end{array}$ & 0 & 0 & 0 & 3 & 0 & 0 \\
\hline 2 & \#amine & no. of basic amines & 0 & 1 & 1 & 2 & 0 & 0 \\
\hline 3 & \#amidine & no. of amidines groups & 0 & 0 & 0 & 0 & 0 & 0 \\
\hline 4 & \#acid & no. of carboxylic acid groups & 0 & 0 & 0 & 0 & 0 & 0 \\
\hline 5 & \#amide & no. of amides groups & 0 & 0 & 0 & 1 & 0 & 0 \\
\hline 6 & \#rotor & $\begin{array}{l}\text { no. of rotatable bonds (without } \\
\text { CX3, alkene, amide, small ring) }\end{array}$ & 0 & 3 & 6 & 8 & 1 & 2 \\
\hline 7 & CNS & $\begin{array}{l}\text { a qualitative CNS } \\
\text { activity parameter }\end{array}$ & -2 & 0 & 1 & 2 & -2 & -2 \\
\hline 8 & dipole & computed dipole moment & 0.67 & 1.1 & 3.9 & 8.9 & 9.47 & 10.22 \\
\hline 9 & SASA & solvent accessible surface area & 348 & 487 & 620 & 798 & 584.85 & 617.51 \\
\hline 10 & FOSA & $\begin{array}{l}\text { SASA on saturated carbon and } \\
\text { attached hydrogen }\end{array}$ & 16 & 178 & 314 & 464 & 91.99 & 91.96 \\
\hline 11 & FISA & $\begin{array}{c}\text { SASA on } \mathrm{N}, \mathrm{O} \text {, and } \mathrm{H} \text { attached } \\
\text { to heteroatoms }\end{array}$ & 0 & 0 & 64 & 176 & 167.04 & 210.06 \\
\hline 12 & PISA & $\pi$ component of SASA & 0 & 160 & 292 & 343 & 325.81 & 313.57 \\
\hline 13 & WPSA & $\begin{array}{l}\text { weakly polar component of the } \\
\text { SASA (halogens, } \mathrm{P} \text {, and S) }\end{array}$ & 0 & 0 & 0 & 126 & 0 & 1.94 \\
\hline 14 & volume & $\begin{array}{l}\text { solvent accessible volume }\left(\AA^{3}\right) \\
\text { estimated no. of hydrogen }\end{array}$ & 492 & 830 & 1104 & 1388 & 1002.52 & 1065.46 \\
\hline 15 & donorHB & $\begin{array}{l}\text { bonds that would be donated to } \\
\text { the solvent water } \\
\text { estimated no. of hydrogen }\end{array}$ & 0 & 0 & 1 & 3 & 0 & 2 \\
\hline 16 & accptHB & $\begin{array}{l}\text { bonds that would be accepted } \\
\text { from the solvent water }\end{array}$ & 1 & 2.8 & 5.2 & 8.3 & 6 & 9.5 \\
\hline 17 & glob & $\begin{array}{l}\text { a globularity descriptor } \\
\text { (1 for a sphere) }\end{array}$ & 0.77 & 0.82 & 0.88 & 0.93 & 0.82 & 0.81 \\
\hline 18 & QPpolrz & predicted polarizability $\left(\AA^{3}\right)$ & 14 & 28 & 38 & 49 & 36.43 & 38.19 \\
\hline 19 & $\mathrm{QP} \log \mathrm{Po} / \mathrm{w}$ & octanol-water $\log \mathrm{P}$ & -0.16 & 2.5 & 4.7 & 6.0 & 2.13 & 0.90 \\
\hline 20 & QPlogS & $\begin{array}{l}\text { solubility in } \log \text { (moles/liter) } \\
\log \text { of }\end{array}$ & -6.5 & -4.6 & -2.5 & -0.42 & -3.99 & -3.99 \\
\hline 21 & CIQPlogS & $\begin{array}{l}\text { conformation-independent } \\
\text { solubility }\end{array}$ & -6.3 & -4.2 & -2.3 & 0.36 & -4.16 & -3.77 \\
\hline 22 & QPPCaco & $\begin{array}{l}\text { apparent Caco-2 cell } \\
\text { permeability }\end{array}$ & 0 & 0 & 810 & 3269 & 258.09 & 100.92 \\
\hline 23 & QPlogBB & $\begin{array}{l}\text { brain/blood } \\
\text { partition coefficient }\end{array}$ & -1.2 & -0.06 & 0.75 & 1.2 & -1.12 & -1.65 \\
\hline
\end{tabular}


Table 2. Cont.

\begin{tabular}{|c|c|c|c|c|c|c|c|c|}
\hline \multirow{2}{*}{ S. No. } & \multirow{2}{*}{ Property } & \multirow{2}{*}{ Description } & \multicolumn{4}{|c|}{ Range of Properties in CNS Drugs } & \multirow{2}{*}{ Compound 19} & \multirow{2}{*}{ Compound 20} \\
\hline & & & QL & PL & PU & QU & & \\
\hline 24 & QPPMDCK & $\begin{array}{l}\text { predicted apparent MDCK cell } \\
\text { permeability }(\mathrm{nm} / \mathrm{s})\end{array}$ & 0 & 0 & 634 & 5899 & 114.43 & 42.50 \\
\hline 25 & QPlogKhsa & $\begin{array}{l}\text { prediction of binding to human } \\
\text { serum albumin }\end{array}$ & -1 & 0.04 & 0.78 & 1.04 & -0.11 & -0.34 \\
\hline 26 & HumanOralAbsorption & Human oral absorption & 2 & 3 & 3 & 3 & 3 & 3 \\
\hline 27 & $\begin{array}{l}\text { PercentHuman } \\
\text { OralAbsorption }\end{array}$ & $\begin{array}{l}\text { Percent of human } \\
\text { oral absorption }\end{array}$ & 61 & 95 & 100 & 100 & 82.63 & 68.11 \\
\hline 28 & TPSA & $\begin{array}{c}\text { van der Waals surface area of } \\
\text { polar nitrogen and } \\
\text { oxygen atoms }\end{array}$ & 3.8 & 12 & 54 & 109 & 98.65 & 119.08 \\
\hline 29 & \#NandO & no. of $\mathrm{N}$ and $\mathrm{O}$ atoms & 1 & 2 & 4 & 7 & 7 & 7 \\
\hline 30 & RuleOfFive & $\begin{array}{l}\text { no. of violations of Lipinski's } \\
\text { rule of five }\end{array}$ & 0 & 0 & 0 & 1 & 0 & 0 \\
\hline 31 & RuleOfThree & $\begin{array}{c}\text { no. of violations of Jorgensen's } \\
\text { rule of three }\end{array}$ & 0 & 0 & 0 & 1 & 0 & 0 \\
\hline 32 & \#in34 & $\begin{array}{l}\text { no. of atoms in three- or } \\
\text { four-membered rings }\end{array}$ & 0 & 0 & 0 & 0 & 0 & 0 \\
\hline 33 & \#in56 & $\begin{array}{l}\text { no. of atoms in five- or } \\
\text { six-membered rings }\end{array}$ & 5 & 11 & 17 & 24 & 20 & 20 \\
\hline 34 & \#noncon & $\begin{array}{l}\text { no. of atoms not able to form } \\
\text { conjugation in } \\
\text { nonaromatic rings }\end{array}$ & 0 & 0 & 4 & 10 & 3 & 3 \\
\hline 35 & \#nonHatm & no. of non-H atoms & 8 & 19 & 25 & 30 & 24 & 25 \\
\hline
\end{tabular}

Abbreviations: QL, qualifying lower limit; PL, preferred lower limit; QU, qualifying upper limit; PU, preferred upper limit. \# QL, PL, QU and PU values for CNS drug criteria were obtained from reference [49].

\subsection{In Silico Absorption and Toxicity Profile}

The selected compounds (19 and 20) were evaluated for their absorption and toxicity profile by a bioinformatics tool admetSAR [50]. The results suggested that both the compounds have high blood-brain barrier (BBB) penetration properties as well as high chance of human intestinal absorption. In AMES test, compound 19 was found to be mutagenic, while 20 was non-mutagenic. Carcinogenicity test revealed that both the compounds were non-carcinogens. The LD50 values in rat were also evaluated, a compound with high value is considered as less lethal. The LD50 for compounds $\mathbf{1 9}$ and $\mathbf{2 0}$ were found to be 2.30 and $2.21 \mathrm{~mol} / \mathrm{kg}$, respectively. Overall, compound $\mathbf{2 0}$ has better toxicity profile as compared to compound 19 (Table 3).

Table 3. In-silico absorption and toxicity profile of compounds 19 and 20 obtained from admetSAR server [50].

\begin{tabular}{ccccccc}
\hline Compound & BBB & HIA & HOB & AMES test & Carcinogenicity & $\begin{array}{c}\text { Rat Acute Toxicity } \\
\text { (LD50, mol/kg) }\end{array}$ \\
\hline 19 & Yes & Yes & Yes & Mutagenic & Non-carcinogen & 2.30 \\
\hline 20 & Yes & Yes & Yes & Non-Mutagenic & Non-carcinogen & 2.21 \\
\hline
\end{tabular}

BBB: blood-brain barrier; HIA: human intestinal permeability; HOB: human oral bioavailability; AMES test is to detect a probable mutagen; carcinogenicity estimates the cancer causing ability of a molecule; LD50: lethal dose which could kill $50 \%$ of the population of the organism (rat) on which it is being tested.

\subsection{Analgesic Activity}

The formalin-induced analgesic test is an extensively acknowledged animal nociception model. In order to evaluate both central and peripheral effects of the compound (20), formalin-induced nociception model was selected for analgesic activity. The formalin induced behavioral response comprises two typical phases, stage I and II. Stage I persists up to five minutes after formalin injection and is characterized by acute pain with vigorous licking and biting of the injected site. Stage I consists the action formalin on afferent C-fiber nociceptors. While Stage II starts 10-30 min after formalin injection and persists till $60 \mathrm{~min}$, characterized by periodic licking and biting of the injected site. Stage II imitates 
the action of central sensitization of the spinal dorsal horn neurons [51,52]. Compound 20 was selected for analgesic activity due to its higher potency $\left(\mathrm{IC}_{50} 7.6 \mathrm{nM}\right)$. Compound 20 (suspensions prepared with $0.5 \% \mathrm{CMC}$ ) were administered per oral (p.o, in doses of 5 , 10,30 , and $50 \mathrm{mg} / \mathrm{kg}$ body weight, $4 \mathrm{~h}$ prior to the formalin injection. Gabapentin (GBP), (dissolved in $0.9 \%$ normal saline), was chosen as positive control (reference drug) and administered intraperitoneal (i.p) in $100 \mathrm{mg} / \mathrm{kg}$ dose. GBP exhibited little analgesic effects in Stage I (acute nociception), in comparison to the control (0.5\% CMC). Though, in Stage II, it displayed significant reduction of paw licking and biting, endorsing GBP central effects. However, compound 20, reduced the pain response significantly both in acute (Stage I) and late (Stage II) phases, in a dose-dependent manner. They significantly demonstrated the reduction in pain response, having better potency than the positive control GBP at $30 \mathrm{mg} / \mathrm{kg}$. The duration (in seconds) of paw licking and paw biting throughout Stage I and II is provided in Figure 5.

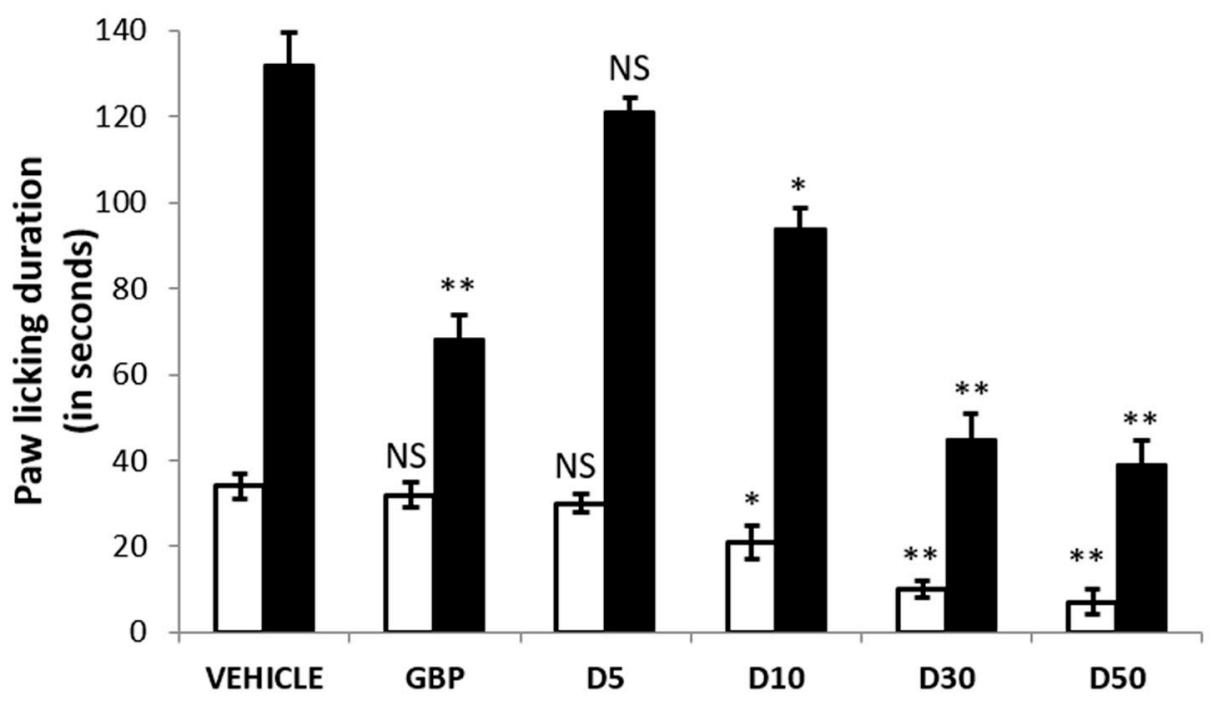

Figure 5. Formalin-induced analgesic test; a dose of the test compound 20 (5, 10, 30, and $50 \mathrm{mg} / \mathrm{kg}$, p.o, suspended in $0.5 \% \mathrm{CMC}$ ) was administered $4 \mathrm{~h}$ before formalin injection ( $50 \mu \mathrm{L}, 2.5 \%)$. Reference drug, gabapentin (100 mg/ $\mathrm{kg}$, i.p, dissolved in $0.9 \%$ normal saline) was injected $30 \mathrm{~min}$ before formalin injection. Total paw licking and biting duration, Stage I (white bar, 0-5 min) and stage II (black bar, 10-30 min) was recorded as a measure of pain behavior. Data is represented as mean \pm SEM from a group of 10 animals. ${ }^{*} p<0.05,{ }^{* *} p<0.01, p>0.05$ (NS, nonsignificant) vs. control (vehicle). GBP: Gabapentin; D5, D10, D30, andD50 are the dose concentrations of test compound 20.

\subsection{Anticancer Activity}

Compounds 19 and 20 were supplied to National Cancer Institute (USA), for sulforhodamine B (SRB) assay and anticancer screening [53,54]. Single-dose $(10 \mu \mathrm{M})$ assay results for compounds $\mathbf{1 9}$ and $\mathbf{2 0}$ were provided as a mean of percent growth $(\% \mathrm{G})$ and growth inhibition (\% GI) against 60 cell lines of nine types of cancers and are tabulated in Table 4. Derivatives 19 (NSC: 778839) and 20 (NSC: 778842) were found to have good anticancer activity towards SNB-75 cell line of CNS cancer, having \% growth inhibition (\% GI) of 35.49 and 31.88, respectively. Compound 20 showed 22.22 and 18.03\% GI of HOP-92 and HOP-62 cell lines of non-small cell lung cancer, respectively. Both the compounds 19 and 20 were also found active on UO-31 renal cancer cell line with \% GI of 21.18 and 29.95, respectively. Compound 19 showed \% GI of 19.99 on T-47D, while compound 20 showed \% GI of 19.89 on MDA-MB-231/ATCC cell lines of breast cancer. 
Table 4. In vitro anticancer screening of compound 19 and 20, against NCI60 cell lines at $10 \mu \mathrm{M}$ concentration.

\begin{tabular}{|c|c|c|c|c|c|}
\hline \multirow{2}{*}{ Panel } & \multirow{2}{*}{ Cell Line } & \multicolumn{2}{|c|}{$\begin{array}{l}\text { Compound } 19 \\
\text { (NSC: 778839) }\end{array}$} & \multicolumn{2}{|c|}{$\begin{array}{l}\text { Compound } 20 \\
\text { (NSC: 778842) }\end{array}$} \\
\hline & & $\% \mathrm{G}$ & $\%$ GI & $\% \mathrm{G}$ & $\%$ GI \\
\hline \multirow{6}{*}{ Leukemia } & CCRF-CEM & 93.58 & 6.42 & 94.48 & 5.52 \\
\hline & HL-60(TB) & 100.09 & -0.09 & 96.15 & 3.85 \\
\hline & K-562 & 98.41 & 1.59 & 98.83 & 1.17 \\
\hline & MOLT-4 & 93.64 & 6.36 & 92.47 & 7.53 \\
\hline & RPMI-8226 & 101.28 & -1.28 & 103.53 & -3.53 \\
\hline & SR & 88.92 & 11.08 & 93.20 & 6.80 \\
\hline \multirow{7}{*}{$\begin{array}{l}\text { Non-Small Cell } \\
\text { Lung Cancer }\end{array}$} & A549/ATCC & 100.60 & -0.60 & 95.28 & 4.72 \\
\hline & HOP-62 & 85.04 & 14.96 & 81.97 & 18.03 \\
\hline & HOP-92 & 104.72 & -4.72 & 77.78 & 22.22 \\
\hline & NCI-H226 & 98.63 & 1.37 & 92.75 & 7.25 \\
\hline & NCI-H23 & 93.07 & 6.93 & 92.19 & 7.81 \\
\hline & NCI-H322M & 94.18 & 5.82 & 99.10 & 0.90 \\
\hline & NCI-H460 & 102.33 & -2.33 & 104.20 & -4.20 \\
\hline \multirow{7}{*}{ Colon Cancer } & COLO 205 & 103.79 & -3.79 & 104.05 & -4.05 \\
\hline & HCC-2998 & 102.05 & -2.05 & 100.24 & -0.24 \\
\hline & HCT-116 & 102.14 & -2.14 & 95.78 & -4.22 \\
\hline & НСТ-15 & 98.10 & 1.9 & 101.16 & -1.16 \\
\hline & HТ29 & 99.25 & 0.75 & 103.23 & -3.23 \\
\hline & KM12 & 105.43 & -5.43 & 101.16 & -1.16 \\
\hline & SW-620 & 102.52 & -2.52 & 102.95 & -2.95 \\
\hline \multirow{6}{*}{ CNS Cancer } & SF-268 & 91.85 & 8.15 & 87.43 & 12.57 \\
\hline & SF-295 & 98.21 & 1.79 & 93.71 & 6.29 \\
\hline & SF-539 & 95.59 & 4.41 & 87.58 & 12.42 \\
\hline & SNB-19 & 99.29 & 0.71 & 97.02 & 2.98 \\
\hline & SNB-75 & 64.51 & 35.49 & 68.12 & 31.88 \\
\hline & U251 & 100.97 & -0.97 & 95.21 & 4.79 \\
\hline \multirow{9}{*}{ Melanoma } & LOX IMVI & 89.06 & 10.94 & 92.99 & 7.01 \\
\hline & MALME-3M & 88.53 & 11.47 & 93.29 & 6.71 \\
\hline & M14 & 101.37 & -1.37 & 98.58 & 1.42 \\
\hline & MDA-MB-435 & 95.05 & 4.95 & 100.55 & -0.55 \\
\hline & SK-MEL-2 & 102.31 & -2.31 & 111.54 & -11.54 \\
\hline & SK-MEL-28 & 111.25 & -11.25 & 101.79 & -1.79 \\
\hline & SK-MEL-5 & 98.72 & 1.28 & 98.82 & -1.18 \\
\hline & UACC-257 & 106.92 & -6.92 & 110.78 & -10.78 \\
\hline & UACC-62 & 97.59 & 2.41 & 92.78 & 7.22 \\
\hline \multirow{7}{*}{$\begin{array}{l}\text { Ovarian } \\
\text { Cancer }\end{array}$} & IGROV1 & 104.14 & -4.14 & 101.63 & -1.63 \\
\hline & OVCAR-3 & 98.56 & 1.44 & 98.53 & 1.47 \\
\hline & OVCAR-4 & 106.27 & -6.27 & 99.47 & 0.53 \\
\hline & OVCAR-5 & 98.30 & 1.70 & 92.08 & 7.92 \\
\hline & OVCAR-8 & 101.95 & -1.95 & 97.49 & 2.51 \\
\hline & $\begin{array}{l}\text { NCI/ADR- } \\
\text { RES }\end{array}$ & 98.37 & 1.63 & 101.45 & -1.45 \\
\hline & SK-OV-3 & 88.34 & 11.66 & 94.77 & 5.23 \\
\hline \multirow{7}{*}{ Renal Cancer } & $786-0$ & 104.06 & -4.06 & 98.99 & 1.01 \\
\hline & A498 & 113.46 & -13.46 & 113.94 & -13.94 \\
\hline & $\mathrm{ACHN}$ & 91.70 & 8.3 & 89.48 & 10.52 \\
\hline & CAKI-1 & 97.19 & 2.81 & 92.35 & 7.65 \\
\hline & SN12C & 97.21 & 2.79 & 95.50 & 4.50 \\
\hline & TK-10 & 110.14 & -10.14 & 114.82 & -14.82 \\
\hline & UO-31 & 78.82 & 21.18 & 70.05 & 29.95 \\
\hline Prostate & PC-3 & 91.14 & 8.86 & 88.11 & 11.89 \\
\hline Cancer & DU-145 & 110.09 & -10.09 & 111.62 & -11.62 \\
\hline \multirow{5}{*}{ Breast Cancer } & MCF7 & 99.19 & 0.81 & 92.32 & 7.68 \\
\hline & $\begin{array}{l}\text { MDA-MB- } \\
231 / \text { ATCC }\end{array}$ & 88.41 & 11.59 & 80.11 & 19.89 \\
\hline & HS 578T & 101.81 & -1.81 & 104.19 & -4.19 \\
\hline & T-47D & 80.01 & 19.99 & 83.24 & 16.24 \\
\hline & MDA-MB-468 & 98.03 & 1.97 & 100.34 & -0.34 \\
\hline
\end{tabular}




\section{Discussion}

Ten benzoxazole clubbed 2-pyrrolidinone derivatives (11-20) as the inhibitors of monoacylglycerol lipase were designed on the criteria fulfilling the structural requirements and on the basis of previously reported inhibitors [36,42-45]. The designed, synthesized, and characterized compounds (11-20) were screened against monoacylglycerol lipase (MAGL) in order to find potential inhibitors. The substituted phenyl derivatives (13-20) were established to reduce the MAGL activity at $100 \mu \mathrm{M}$ concentration below $50 \%$. Compound 19 (4- $\mathrm{NO}_{2}$ derivative) and compound $20\left(4-\mathrm{SO}_{2} \mathrm{NH}_{2}\right.$ derivative) were the most potent, with $\mathrm{IC}_{50}$ of 8.4 and $7.6 \mathrm{nM}$, correspondingly. The benzoxazole derivatives having 4$\mathrm{NO}_{2}$ phenyl (19) and 4- $\mathrm{SO}_{2} \mathrm{NH}_{2}$ phenyl (20), with an FAAH IC 50 value greater than $50 \mu \mathrm{M}$, were considered selective MAGL inhibitors. In molecular docking studies, compounds 19 and 20 showed comparable docking scores of -9.87 and -9.83 , respectively. The binding of compounds 19 and 20 in the active site of MAGL revealed that the carbonyl group of pyrrolidinone is located exactly in the oxyanion hole and stabilized by three hydrogen bonds ( $2 \AA$ ) with alanine 51 , serine 122 , and methionine 123 . Serine 122 is one of the critical amino acid residues of the catalytic triad of MAGL. The benzoxazole moiety is found to be positioned in the amphiphilic pouch, having $\pi-\pi$ stacking contacts with the amino acid tyrosine 194. The 4- $\mathrm{NO}_{2}$ phenyl (19) and 4- $\mathrm{SO}_{2} \mathrm{NH}_{2}$ phenyl (20) part of the ligand was engaged in hydrophobic (Van der Waals) attractions with the amino acids leucine 148, 213, and 241. The binding patterns of compounds 19 and 20 in the catalytic site of MAGL were found to be similar as those of the reported inhibitors bound crystal structures [32,36,39,41]. Remarkably, the physiochemical and pharmacokinetic properties of compounds 19 and 20 computed by QikProp were found to be in the qualifying range as per the proposed guideline for good orally bioactive CNS drugs. Moreover, compound 20 showed better toxicity profile than compound 19 , as predicted by admetSAR [50]. In formalin-induced analgesic test, compound 20 reduced the pain response significantly both in acute (stage I) and late (stage II) phases in a dose-dependent manner. It significantly demonstrated the reduction in pain response, having better potency than the positive control GBP, at the dose of $30 \mathrm{mg} / \mathrm{kg}$. Moreover, in one dose $(10 \mu \mathrm{M})$, anticancer screening by SRB assay, compounds 19 (NSC: 778839) and 20 (NSC: 778842) were found to have good anticancer activity towards SNB-75 cell line of CNS cancer, having \% growth inhibition (\% GI) of 35.49 and 31.88, respectively. Therefore, the present work concluded that compound 20 is the potential lead compounds that can be further manipulated at points 1 and 4 of the 2-pyrrolidinone moiety for the discovery and development of more selective and potent inhibitors of MAGL for neuropathic pain and CNS disorders including cancers.

\section{Experimental}

\subsection{Chemistry}

Reagents and solvents were procured from Merck Ltd. (New Delhi, India) and Sigma-Aldrich Ltd. (New Delhi, India). Progress and completion of the reactions was checked by thin-layer chromatography (TLC). Melting points of the derivatives were determined by open tube capillary method and uncorrected. Elemental analysis data were obtained from CHNOS elemental analyzer (Vario EL III, Elementar Analysensysteme $\mathrm{GmbH}$, Langenselbold, Germany). Shimadzu FT-IR spectrometer (Shimadzu Analytical Pvt. Ltd., New Delhi, India) was used for recording IR spectrum $\left(4000-400 \mathrm{~cm}^{-1}\right)$, by preparing $\mathrm{KBr}$ pellets. ${ }^{1} \mathrm{H}-\mathrm{NMR}$ spectrum of the derivatives were obtained from Bruker $300 \mathrm{MHz}$ NMR instrument (Bruker Avance AV-III type, Billerica, MA, USA) using $\mathrm{CDCl}_{3}$ or DMSO$d_{6}$ as solvent. ${ }^{1} \mathrm{H}-\mathrm{NMR}$ spectra of compounds 11-20 can be found in the Supplementary Material. Molecular mass $(m / z)$ of the derivatives were obtained by UPLC-MS (Q-TOF-ESI) (Waters Corp., Milford, MA, USA). 
4.1.1. Synthesis of 1-(Aryl Substituted)-5-Oxopyrrolidine-3-Carboxylic Acids (1-10)

Method-1 (for compound 1)

Equimolar amount of benzylamine $(50 \mathrm{mmol})$ and itaconic acid $(50 \mathrm{mmol}, 6.5 \mathrm{~g})$ in $50 \mathrm{~mL}$ of tripled distilled water was refluxed for about $45-60 \mathrm{~min}$. The contents were then chilled, filtered, and washed with cold water. The obtained solid was dissolved in minimum quantity of aq. $\mathrm{NaOH}(10 \%)$. After treatment with activated charcoal, the solution was filtered and acidified with dil. $\mathrm{HCl}$ in order to obtain the precipitate. The filtered solid was washed with cold water, dried, and purified by recrystallization from ethanol/water mixture.

1-Benzyl-5-Oxopyrrolidine-3-Carboxylic Acid (1), white solid; yield: 75\%; m.p. 142-145 ${ }^{\circ}$ C; IR: $1518(\mathrm{C}=\mathrm{C}), 1627(\mathrm{C}=\mathrm{OOH}), 1734(\mathrm{C}=\mathrm{O}), 2947\left(\mathrm{sp}_{3} \mathrm{C}-\mathrm{H}\right), 3045(\mathrm{Ar} \mathrm{C}-\mathrm{H}), 3241(\mathrm{COO}-\mathrm{H}) ;{ }^{1} \mathrm{H}-$ NMR (DMSO- $\left.d_{6}\right) \delta(\mathrm{ppm}): 2.63-2.76\left(\mathrm{~m}, 2 \mathrm{H}, \mathrm{COCH}_{2}\right), 3.62\left(\mathrm{~s}, 2 \mathrm{H}, \mathrm{CH}_{2}\right), 4.29-4.44(\mathrm{~m}, 3 \mathrm{H}$, $\mathrm{NCH}_{2}$ and $\left.\mathrm{CH}_{\text {pyrr }}\right), 7.20-7.36(\mathrm{~m}, 5 \mathrm{H}, \mathrm{Ar}-\mathrm{H}), 11.35$ (s, $1 \mathrm{H}, \mathrm{COOH}, \mathrm{D}_{2} \mathrm{O}$ exchangeable); ESI-MS (m/z): 219.12 [M] ${ }^{+}$; Anal. calcd. For $\mathrm{C}_{12} \mathrm{H}_{13} \mathrm{NO}_{3}: \mathrm{C}, 65.74 ; \mathrm{H}, 5.98 ; \mathrm{N}, 6.39$. Found: C, 65.80; $\mathrm{H}, 5.85 ; \mathrm{N}, 6.50$.

Method-1 (for compound 1) Method-2 (for compounds 2-10)

Intermediate compounds (2-10) were synthesized as per the procedure reported in our previous publication [45].

\subsubsection{Synthesis of 4-(Benzoxazolyl)-1-(Aryl Substituted)Pyrrolidin-2-Ones (11-20)}

Appropriate 1-(aryl substituted)-5-oxopyrrolidine-3-carboxylic acids $(20 \mathrm{mmol}), 2$ aminophenol (20 mmol, $2.18 \mathrm{~g}$ ) and polyphosphoric acid ( $20 \mathrm{~g})$ in an RBF were heated to $150-160^{\circ} \mathrm{C}$ and stirred for $2-3 \mathrm{~h}$. The content of the RBF (round bottom flask) was cooled at $\mathrm{RT} ; 5 \% \mathrm{NaCO}_{3}(25 \mathrm{~mL})$ was added and heated for $10 \mathrm{~min}$. The content was chilled and transferred in a flask having $100 \mathrm{~mL}$ of water, and stirred at RT for $15 \mathrm{~min}$. The filtered solid was washed three times with water $(50 \mathrm{~mL})$, dried, and purified by recrystallization with ethanol. The derivatives were then purified by chromatography using ethylacetate:hexane (1:4) as solvent.

4-(Benzo[d]oxazol-2-yl)-1-benzylpyrrolidin-2-one (11), pale-yellow solid; yield: 57\%; m.p. 160-162 ${ }^{\circ} \mathrm{C}$; IR: $1370(\mathrm{C}-\mathrm{N}), 1555(\mathrm{C}=\mathrm{C}), 1621(\mathrm{C}=\mathrm{N}), 1703(\mathrm{C}=\mathrm{O}), 3077(\mathrm{Ar} \mathrm{C}-\mathrm{H}) ;{ }^{1} \mathrm{H}-\mathrm{NMR}$ $\left(\mathrm{DMSO}_{-} \mathrm{d}_{6}\right) \delta(\mathrm{ppm}): 2.60-2.77\left(\mathrm{~m}, 2 \mathrm{H}, \mathrm{COCH}_{2}\right), 3.13-3.18\left(\mathrm{~m}, 1 \mathrm{H}, \mathrm{CH}_{\text {pyrr }}\right), 3.81-3.86(\mathrm{~m}$, $\left.2 \mathrm{H}, \mathrm{NCH}_{2}\right), 3.95-4.01\left(\mathrm{~m}, 2 \mathrm{H}, \mathrm{CH}_{2}\right), 7.38-7.58(\mathrm{~m}, 6 \mathrm{H}, \mathrm{Ar}-\mathrm{H}), 7.73-7.78(\mathrm{~d}, 1 \mathrm{H}, \mathrm{Ar}-\mathrm{H}$, $J=15.6 \mathrm{~Hz}), 7.94-7.96(\mathrm{~d}, 2 \mathrm{H}, \mathrm{Ar}-\mathrm{H}, J=8.4 \mathrm{~Hz})$; ESI-MS $(m / z): 292.14[\mathrm{M}]^{+}, 293.14[\mathrm{M}+\mathrm{H}]^{+}$; Anal. calcd. for $\mathrm{C}_{18} \mathrm{H}_{16} \mathrm{~N}_{2} \mathrm{O}_{2}$ : C, 73.95; $\mathrm{H}, 5.52 ; \mathrm{N}$, 9.58. Found: $\mathrm{C}, 74.16 ; \mathrm{H}, 5.70 ; \mathrm{N}, 9.82$.

4-(Benzo[d]oxazol-2-yl)-1-phenylpyrrolidin-2-one (12), pale-yellow solid; yield: 67\%; m.p. 148-150 ${ }^{\circ} \mathrm{C}$; IR: 1395 (C-N), $1552(\mathrm{C}=\mathrm{C}), 1615(\mathrm{C}=\mathrm{N}), 1698$ (C=O), $3070(\mathrm{Ar} \mathrm{C}-\mathrm{H}){ }^{1} \mathrm{H}-\mathrm{NMR}$ (DMSO- $\left.d_{6}\right) \delta(\mathrm{ppm}): 2.86-3.20\left(\mathrm{~m}, 2 \mathrm{H}, \mathrm{COCH}_{2}\right), 4.16-4.40\left(\mathrm{~m}, 3 \mathrm{H}, \mathrm{NCH}_{2}\right.$ and $\left.\mathrm{CH}_{\text {pyrr }}\right)$, 7.16-8.18 (m, 9H, Ar-H); ESI-MS ( $m / z): 278.13\left[\mathrm{M}^{+}, 279.13[\mathrm{M}+\mathrm{H}]^{+}\right.$; Anal. calcd. for $\mathrm{C}_{17} \mathrm{H}_{14} \mathrm{~N}_{2} \mathrm{O}_{2}$ : C, 73.37; H, 5.07; N, 10.07. Found: $\mathrm{C}, 73.60 ; \mathrm{H}, 5.18 ; \mathrm{N}, 10.33$.

4-(Benzo[d]oxazol-2-yl)-1-(o-tolyl)pyrrolidin-2-one (13), pale-yellow solid; yield: 68\%; m.p. 162-164 ${ }^{\circ} \mathrm{C}$; IR: $1404(\mathrm{C}-\mathrm{N}), 1568(\mathrm{C}=\mathrm{C}), 1607(\mathrm{C}=\mathrm{N}), 1691$ (C=O), 3079 (Ar C-H); ${ }^{1} \mathrm{H}-\mathrm{NMR}$ $\left(\mathrm{DMSO}_{6} \mathrm{~d}_{6}\right) \delta(\mathrm{ppm}): 2.18\left(\mathrm{~s}, 3 \mathrm{H}, \mathrm{CH}_{3}\right), 2.88-3.17\left(\mathrm{~m}, 2 \mathrm{H}, \mathrm{COCH}_{2}\right), 4.12-4.18(\mathrm{~m}, 1 \mathrm{H}$, $\left.\mathrm{CH}_{\text {pyrr }}\right), 4.26-4.39\left(\mathrm{~m}, 2 \mathrm{H}, \mathrm{NCH}_{2}\right), 7.18-7.21\left(\mathrm{~m}, 2 \mathrm{H}, \mathrm{H}-5_{\text {phenyl }}\right.$ and $\left.\mathrm{H}-6_{\text {phenyl }}\right), 7.36-7.54(\mathrm{~m}$, $4 \mathrm{H}, \mathrm{H}-5_{\text {benzoxazole }}, \mathrm{H}-6_{\text {benzoxazole }}, \mathrm{H}-3_{\text {phenyl }}$ and $\left.\mathrm{H}-4_{\text {phenyl }}\right), 7.98-8.01\left(\mathrm{~d}, 1 \mathrm{H}, \mathrm{H}-7_{\text {benzoxazole }}\right.$ $J=8.1 \mathrm{~Hz}), 8.09-8.12\left(\mathrm{~d}, 1 \mathrm{H}, \mathrm{H}-4_{\text {benzoxazole }}, J=7.8 \mathrm{~Hz}\right)$; ESI-MS $(\mathrm{m} / \mathrm{z}): 292.13[\mathrm{M}]^{+}, 293.13$ $[\mathrm{M}+\mathrm{H}]^{+}$; Anal. calcd. for $\mathrm{C}_{18} \mathrm{H}_{16} \mathrm{~N}_{2} \mathrm{O}_{2}: \mathrm{C}, 73.95 ; \mathrm{H}, 5.52 ; \mathrm{N}, 9.58$. Found: $\mathrm{C}, 74.21 ; \mathrm{H}, 5.82$; $\mathrm{N}, 9.77$.

4-(Benzo[d]oxazol-2-yl)-1-(p-tolyl)pyrrolidin-2-one (14), pale-yellow solid; yield: 67\%; m.p. 164-166 ${ }^{\circ} \mathrm{C}$; IR: $1411(\mathrm{C}-\mathrm{N}), 1562(\mathrm{C}=\mathrm{C}), 1598(\mathrm{C}=\mathrm{N}), 1697$ (C=O), 3077 (Ar C-H); ${ }^{1} \mathrm{H}-\mathrm{NMR}$ $\left(\mathrm{DMSO}_{6}\right) \delta(\mathrm{ppm}): 2.28\left(\mathrm{~s}, 3 \mathrm{H}, \mathrm{CH}_{3}\right), 2.94-3.13\left(\mathrm{~m}, 2 \mathrm{H}, \mathrm{COCH}_{2}\right), 4.13-4.35(\mathrm{~m}, 3 \mathrm{H}$, $\mathrm{NCH}_{2}$ and $\left.\mathrm{CH}_{\text {pyrr }}\right), 7.17-7.20\left(\mathrm{~d}, 2 \mathrm{H}, \mathrm{H}-3_{\text {phenyl }}\right.$ and $\left.\mathrm{H}-5_{\text {phenyl }}, J=8.4 \mathrm{~Hz}\right), 7.34-7.42(\mathrm{~m}$, 
$2 \mathrm{H}, \mathrm{H}-2_{\text {phenyl }}$ and H-6 $\left.6_{\text {phenyl }}\right), 7.54-7.57\left(\mathrm{~d}, 2 \mathrm{H}, \mathrm{H}-4_{\text {benzoxazole }}\right.$ and $\mathrm{H}-7_{\text {benzoxazole, }} J=8.4$

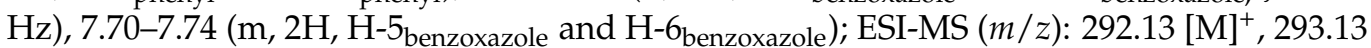
$[\mathrm{M}+\mathrm{H}]^{+}$; Anal. calcd. for $\mathrm{C}_{18} \mathrm{H}_{16} \mathrm{~N}_{2} \mathrm{O}_{2}: \mathrm{C}, 73.95 ; \mathrm{H}, 5.52 ; \mathrm{N}, 9.58$. Found: C, 74.18; H, 5.78; $\mathrm{N}, 9.80$.

4-(Benzo[d]oxazol-2-yl)-1-(4-chlorophenyl)pyrrolidin-2-one (15), pale-yellow solid; yield: 70\%; m.p. 174-176 ${ }^{\circ} \mathrm{C}$; IR: 758 (C-Cl), 1396 (C-N), 1568 (C=C), 1612 (C=N), 1689 (C=O), 3086 (Ar C-H) ${ }^{1} \mathrm{H}-\mathrm{NMR}$ (DMSO- $\left.d_{6}\right) \delta$ (ppm): 3.01-3.09 (m, 2H, $\left.\mathrm{COCH}_{2}\right), 4.20-4.33\left(\mathrm{~m}, 3 \mathrm{H}, \mathrm{NCH}_{2}\right.$ and $\left.\mathrm{CH}_{\text {pyrr }}\right), 7.35-7.43(\mathrm{~m}, 4 \mathrm{H}, \mathrm{Ar}-\mathrm{H}), 7.68-7.72(\mathrm{t}, 4 \mathrm{H}, \mathrm{Ar}-\mathrm{H}, \mathrm{J}=6.3 \mathrm{~Hz})$; ESI-MS $(\mathrm{m} / \mathrm{z})$ : $312.11[\mathrm{M}]^{+}, 314.10[\mathrm{M}+2]^{+}$; Anal. calcd. for $\mathrm{C}_{17} \mathrm{H}_{13} \mathrm{ClN}_{2} \mathrm{O}_{2}: \mathrm{C}, 65.29 ; \mathrm{H}, 4.19 ; \mathrm{N}, 8.96$. Found: C, 65.52; H, 4.35; N, 9.03.

4-(Benzo[d]oxazol-2-yl)-1-(3-chloro-4-fluorophenyl)pyrrolidin-2-one (16), pale-yellow solid; yield: 68\%; m.p. 187-189 ${ }^{\circ} \mathrm{C}$; IR: 765 (C-Cl), 1388 (C-N), $1545(\mathrm{C}=\mathrm{C}), 1613(\mathrm{C}=\mathrm{N}), 1690(\mathrm{C}=\mathrm{O})$, 3098 (Ar C-H); ${ }^{1} \mathrm{H}-\mathrm{NMR}\left(\mathrm{DMSO}_{6}\right) \delta(\mathrm{ppm}):$ 2.92-3.19 (m, 2H, COCH$)_{2}, 4.13-4.21(\mathrm{~m}, 1 \mathrm{H}$, $\left.\mathrm{CH}_{\text {pyrr }}\right), 4.25-4.41$ (m, 2H, $\left.\mathrm{NCH}_{2}\right), 7.41-7.60$ (m, 5H, Ar-H), 8.05-8.08 (d, 1H, H-7 benzoxazole, $J=8.1 \mathrm{~Hz}), 8.11-8.14\left(\mathrm{~d}, 1 \mathrm{H}, \mathrm{H}-4_{\text {benzoxazole }^{\prime}} J=8.1 \mathrm{~Hz}\right)$; ESI-MS $(\mathrm{m} / z): 330.10\left[\mathrm{M}^{+}, 332.09\right.$ $[\mathrm{M}+2]^{+}$; Anal. calcd. for $\mathrm{C}_{17} \mathrm{H}_{12} \mathrm{ClFN}_{2} \mathrm{O}_{2}$ : C, 61.73; H, 3.66; N, 8.47. Found: $\mathrm{C}, 62.07 ; \mathrm{H}$, $3.85 ; \mathrm{N}, 8.61$.

4-(Benzo[d]oxazol-2-yl)-1-(4-hydroxyphenyl)pyrrolidin-2-one (17), pale-yellow solid; yield: 62\%; m.p. $242-245^{\circ} \mathrm{C}$; IR: $1407(\mathrm{C}-\mathrm{N}), 1535(\mathrm{C}=\mathrm{C}), 1597(\mathrm{C}=\mathrm{N}), 1698(\mathrm{C}=\mathrm{O}), 3092(\mathrm{Ar} \mathrm{C}-\mathrm{H})$, $3410(\mathrm{O}-\mathrm{H}) ;{ }^{1} \mathrm{H}-\mathrm{NMR}\left(\mathrm{DMSO}-d_{6}\right) \delta(\mathrm{ppm}): 2.91-3.20\left(\mathrm{~m}, 2 \mathrm{H}, \mathrm{COCH}_{2}\right), 4.12-4.23(\mathrm{~m}, 1 \mathrm{H}$, $\left.\mathrm{CH}_{\text {pyrr }}\right), 4.25-4.39$ (m, 2H, $\left.\mathrm{NCH}_{2}\right), 5.64$ (bs, 1H, OH, $\mathrm{D}_{2} \mathrm{O}$ exchangeable), 7.41-7.60 (m, 4H, Ar- $\left.\mathrm{H}_{\text {phenyl }}\right), 7.72-7.77\left(\mathrm{t}, 2 \mathrm{H}, \mathrm{H}-5_{\text {benzoxazole }}\right.$ and $\left.\mathrm{H}-6_{\text {benzoxazole }}, J=7.5 \mathrm{~Hz}\right), 7.96-7.99(\mathrm{~d}, 1 \mathrm{H}$, H-7 benzoxazole,$J=8.4 \mathrm{~Hz}), 8.08-8.10\left(\mathrm{~d}, 1 \mathrm{H}, \mathrm{H}-4_{\text {benzoxazole }}, J=8.4 \mathrm{~Hz}\right)$; ESI-MS $(\mathrm{m} / \mathrm{z}): 294.12$ $[\mathrm{M}]^{+}, 295.12[\mathrm{M}+\mathrm{H}]^{+}$; Anal. calcd. for $\mathrm{C}_{17} \mathrm{H}_{14} \mathrm{~N}_{2} \mathrm{O}_{3}: \mathrm{C}, 69.38 ; \mathrm{H}, 4.79 ; \mathrm{N}, 9.52$. Found: $\mathrm{C}$, 69.66; H, 4.97; N, 9.78.

4-(Benzo[d]oxazol-2-yl)-1-(4-methoxyphenyl)pyrrolidin-2-one (18), pale-yellow solid; yield: 66\%; m.p. 177-179 ${ }^{\circ}$ C; IR: 1412 (C-N), 1546 (C=C), $1600(\mathrm{C}=\mathrm{N}), 1690(\mathrm{C}=\mathrm{O}), 3081$ (Ar C-H); ${ }^{1} \mathrm{H}-\mathrm{NMR}\left(\mathrm{DMSO}-\mathrm{d}_{6}\right) \delta(\mathrm{ppm}): 2.88-3.18\left(\mathrm{~m}, 2 \mathrm{H}, \mathrm{COCH}_{2}\right), 3.67\left(\mathrm{~s}, 3 \mathrm{H}, \mathrm{OCH}_{3}\right), 4.08-4.16(\mathrm{~m}$, $\left.1 \mathrm{H}, \mathrm{CH}_{\text {pyrr }}\right), 4.22-4.39\left(\mathrm{~m}, 2 \mathrm{H}, \mathrm{NCH}_{2}\right), 7.16-7.19\left(\mathrm{~d}, 2 \mathrm{H}, \mathrm{H}-2\right.$ phenyl and $\left.\mathrm{H}-6_{\text {phenyl }}, J=8.4 \mathrm{~Hz}\right)$, 7.42-7.58 (m, 4H, H-5 benzoxazole H- $6_{\text {benzoxazole, }} \mathrm{H}-3_{\text {phenyl }}$ and $\left.\mathrm{H}-5_{\text {phenyl }}\right), 7.95-7.98(\mathrm{~d}, 1 \mathrm{H}$, H-7 benzoxazole $J=8.4 \mathrm{~Hz}), 8.09-8.12\left(\mathrm{~d}, 1 \mathrm{H}, \mathrm{H}-4_{\text {benzoxazole }}, J=8.4 \mathrm{~Hz}\right)$; ESI-MS $(\mathrm{m} / \mathrm{z}): 308.13$ $[\mathrm{M}]^{+}, 309.13[\mathrm{M}+\mathrm{H}]^{+}$; Anal. calcd. for $\mathrm{C}_{18} \mathrm{H}_{16} \mathrm{~N}_{2} \mathrm{O}_{3}: \mathrm{C}, 70.12 ; \mathrm{H}, 5.23 ; \mathrm{N}, 9.09$. Found: $\mathrm{C}$, 70.35; H, 5.38; N, 9.18.

4-(Benzo[d]oxazol-2-yl)-1-(4-nitrophenyl)pyrrolidin-2-one (19), yellow solid; yield: 62\%; m.p. 276-278 ${ }^{\circ} \mathrm{C}$; IR: 1405 (C-N), 1550 (C=C), 1595 (C=N), 1695 (C=O), 3089 (Ar C-H); ${ }^{1} \mathrm{H}-\mathrm{NMR}$ (DMSO-d $\left.{ }_{6}\right) \delta$ (ppm): 2.89-3.15 (m, 2H, $\left.\mathrm{COCH}_{2}\right), 4.11-4.16\left(\mathrm{~m}, 1 \mathrm{H}, \mathrm{CH}_{\text {pyrr }}\right), 4.24-4.37(\mathrm{~m}, 2 \mathrm{H}$, $\left.\mathrm{NCH}_{2}\right), 6.79-6.82\left(\mathrm{~d}, 2 \mathrm{H}, \mathrm{H}-2_{\text {phenyl }}\right.$ and $\left.\mathrm{H}-6_{\text {phenyl }}, J=9 \mathrm{~Hz}\right), 7.43-7.48\left(\mathrm{t}, 2 \mathrm{H}, \mathrm{H}-5_{\text {benzoxazole }}\right.$ H-6 $\left.6_{\text {benzoxazole }} J=7.5 \mathrm{~Hz}\right), 8.01-8.18\left(\mathrm{~m}, 4 \mathrm{H}, \mathrm{H}-4_{\text {benzoxazole }}, \mathrm{H}-7_{\text {benzoxazole }}, \mathrm{H}-3_{\text {phenyl }}\right.$ and H-5 phenyl); ESI-MS (m/z): $323.11[\mathrm{M}]^{+}, 324.11[\mathrm{M}+\mathrm{H}]^{+}$; Anal. calcd. for $\mathrm{C}_{17} \mathrm{H}_{13} \mathrm{~N}_{3} \mathrm{O}_{4}$ : C, 63.16; H, 4.05; N, 13.00. Found: C, 63.35; H, 4.27; N, 13.23.

4-(4-(Benzo[d]oxazol-2-yl)-2-oxopyrrolidin-1-yl)benzenesulfonamide (20), yellow solid; yield: 60\%; m.p. 227-229 ${ }^{\circ} \mathrm{C}$; IR: 1416 (C-N), 1564 (C=C), $1607(\mathrm{C}=\mathrm{N}), 1704$ (C=O), 3095 (Ar $\mathrm{C}-\mathrm{H}) ;{ }^{1} \mathrm{H}-\mathrm{NMR}$ (DMSO-d 6 ) $\delta$ (ppm): 2.91-3.19 (m, 2H, $\left.\mathrm{COCH}_{2}\right), 4.15-4.22\left(\mathrm{~m}, 1 \mathrm{H}, \mathrm{CH}_{\text {pyrr }}\right.$ ), 4.25-4.38 (m, 2H, $\left.\mathrm{NCH}_{2}\right), 5.67$ (s, 2H, $\mathrm{SO}_{2} \mathrm{NH}_{2}, \mathrm{D}_{2} \mathrm{O}$ exchangeable), 7.42-7.59 (m, 4H, Ar-H), 8.09-8.16 (m, 4H, Ar-H); ESI-MS (m/z): $357.12[\mathrm{M}]^{+}, 358.12[\mathrm{M}+\mathrm{H}]^{+}$; Anal. calcd. for $\mathrm{C}_{17} \mathrm{H}_{15} \mathrm{~N}_{3} \mathrm{O}_{4} \mathrm{~S}: \mathrm{C}, 57.13 ; \mathrm{H}, 4.23 ; \mathrm{N}, 11.76$. Found: $\mathrm{C}, 57.36 ; \mathrm{H}, 4.36 ; \mathrm{N}, 11.95$.

\subsection{Human MAGL Assay}

The screening of the synthesized compounds (11-20) for their capability to reduce $h$ MAGL activity was performed according to the information leaflet provided with Cayman's assay kit (Cayman Chemical, Michigan, USA) by the reported method [29], as 
discussed in detail in our previous publication [45]. The results were compared with standard MAGL inhibitors, CAY10499 and JZL184, and are provided in Table 1.

\subsection{Human FAAH Assay}

The screening of the selected compounds $(15,16,18,19$ and 20) for their potential to inhibit $h$ FAAH was performed according to the information leaflet provided with Cayman's assay kit (Cayman Chemical, Ann Arbor, Michigan, USA) by the reported method [47], as discussed in detail in our previous publication [45]. The results were compared with standard FAAH inhibitor, URB597, and are provided in Table 1.

\subsection{Molecular Docking Study}

Glide executed on Maestro 9.4 (Schrödinger Inc., New York, NY, USA) was utilized for Glide XP docking of active compounds (19 and 20). The .pdb file of $h$ MAGL X-ray crystal structure was downloaded from protein data bank having ID 5ZUN (crystal structure resolution $1.35 \AA$ ) for molecular docking study [36]. The protein structure was refined, optimized, and energy-minimized with the help of preparation wizard in Maestro. A docking grid of $20 \times 20 \times 20 \AA$, was created around the catalytic site by defining the cocrystallized ligand. Ligand (compounds 19 and 20) structures were prepared with the help of LigPrep 2.6 with Epik 2.4 at pH $7.0 \pm 2.0$. The methodology was validated by docking the cocrystallized ligand with Glide XP docking protocol [55].

\subsection{Physicochemical and Pharmacokinetic Characteristics}

Guidelines, concerning the validation and optimization of orally active CNS compounds, were developed by Ghose et. al. by analyzing 35 characteristic features of orally bioavailable $317 \mathrm{CNS}$ and 626 non-CNS drugs [49]. For computations of these properties of the selected compounds (19 and 20), QikProp 3.6 module of Schrodinger was utilized. The generated data was then matched with the qualifying range as per the suggested guideline for good orally bioactive CNS drugs.

\subsection{In Silico Absorption and Toxicity Profile}

The selected compounds (19 and 20) were evaluated for their absorption and toxicity profile by a bioinformatics tool admetSAR [50]. Oral bioavailability, intestinal absorption, and BBB penetration properties were calculated. AMES test for mutagenicity, carcinogenicity test, and the calculation of LD50 for both the compounds (19 and 20) were also evaluated.

\subsection{Analgesic Activity}

Formalin-induced analgesic test was executed by the procedure described by Coderre and Laughlin [51,52] as discussed in detail in our previous publication [45]. Male Wistar rats (180-200 g) were obtained with the permission of IAEC (proposal number 1048) from Jamia Hamdard, New Delhi, India. The results of test compound 20 and reference drug, Gabapentin (GBP), were statistically compared with the control group.

\subsection{Anticancer Screening: Sulforhodamine B Assay}

Compounds 19 and 20 were supplied to National Cancer Institute (Bethesda, Maryland, USA), for in vitro sulforhodamine B (SRB) assay, anticancer screening on 60 cell lines of cancers of leukemia, melanoma, and tumors of the kidney, brain, breast, lung, colon, ovary, and prostate, as per their standard protocol [53,54]. One dose anticancer results (NCI, USA) of compounds $\mathbf{1 9}$ and $\mathbf{2 0}$ are provided in the Supplementary Materials.

\subsection{Statistical Analysis}

The statistical study of the data was accomplished by GraphPad Prism (version 8.0.2; GraphPad Software, San Diego, CA, USA). The dose response of the test compounds was 
compared with that of control, in formalin-induced analgesic test, by analysis of variance (ANOVA) followed by Dunnett's test. Outcomes are communicated as mean $\pm \mathrm{SEM}$.

\section{Conclusions}

Ten benzoxazole clubbed 2-pyrrolidinone derivatives (11-20) as the inhibitors of MAGL were designed, synthesized, characterized, and assayed against MAGL and FAAH enzymes, in order to find potential small molecule selective MAGL inhibitor. Compounds 19 (4- $\mathrm{NO}_{2}$ derivative) and $20\left(4-\mathrm{SO}_{2} \mathrm{NH}_{2}\right.$ derivative) were found most potent and selective, with an $\mathrm{IC}_{50}$ of 8.4 and $7.6 \mathrm{nM}$, respectively. The binding patterns of compounds 19 and $\mathbf{2 0}$ in the catalytic site of MAGL were found as expected and similar as those of the reported inhibitors.

The physiochemical and pharmacokinetic properties of compounds 19 and 20 were found to be almost in the qualifying range as per the proposed guideline for good orally bioactive CNS drugs. Compound 20 significantly demonstrated the reduction in pain response, having better potency than the positive control GBP, at the dose of $30 \mathrm{mg} / \mathrm{kg}$. The present work concluded that compound 20 is the potential lead compounds that can be further studied and optimized at points 1 and 4 of the 2-pyrrolidinone moiety for the discovery and development of more selective and potent inhibitors of MAGL for neuropathic pain.

Supplementary Materials: The following are available online, ${ }^{1} \mathrm{H}-\mathrm{NMR}$ spectra of compounds 11-20 and one dose anticancer results (NCI, USA) of compounds 19 and 20 is provided in the supporting information.

Author Contributions: Conceptualization, O.A., A.S.A.A. and H.K.S.; data curation, O.A., M.Q.H. and M.M.S.; formal analysis, A.S.A.A., Y.R., M.Q.H. and H.K.S.; funding acquisition, A.S.A.A. and O.A.; investigation, O.A., M.Q.H. and M.M.S.; methodology, O.A. and M.Q.H.; project administration, A.S.A.A., O.A. and Y.R.; resources, A.S.A.A., O.A., M.Q.H. and H.K.S.; software, O.A., M.Q.H. and H.K.S.; supervision, O.A., A.S.A.A. and M.Q.H.; validation, A.S.A.A., Y.R., M.Q.H., M.M.S. and H.K.S.; visualization, Y.R., M.Q.H., M.M.S. and H.K.S.; writing—original draft, O.A.; writing-review and editing, M.Q.H., Y.R., M.M.S. and H.K.S. All authors have read and agreed to the published version of the manuscript.

Funding: Authors would like to thank the Deanship of Scientific Research at Prince Sattam Bin Abdulaziz University for providing financial support for this project (grant no. 2019/03/11064).

Institutional Review Board Statement: The study was conducted according to the guidelines of the Declaration of Helsinki, and approved by the Institutional Animal Ethics Committee (Proposal number 1048) of Jamia Hamdard (Hamdard University, New Delhi-110062 (Registration Number: 173/CPCSEA; 28 January 2000).

Informed Consent Statement: Not applicable.

Data Availability Statement: The data presented in this study are available on request from the corresponding authors.

Acknowledgments: Authors would like to thank the Deanship of Scientific Research at Prince Sattam Bin Abdulaziz University for providing financial support for this project (grant no. 2019/03/11064).

Conflicts of Interest: Authors declare that they do not have any conflict of interest.

Sample Availability: The samples of the compounds are available on request from the corresponding author.

\section{References}

1. Di Marzo, V.; Bisogno, T.; De Petrocellis, L. the biosynthesis, fate and pharmacological properties of endocannabinoids. Handb. Exp. Pharmacol. 2005, 168, 147-185. [CrossRef]

2. Sugiura, T.; Kondo, S.; Sukagawa, A.; Nakane, S.; Shinoda, A.; Itoh, K. 2- Arachidonoylglycerol: A possible endogenous can-nabinoid receptor ligand in brain. Biochem. Biophys. Res. Commun. 1995, 215, 89-97. [CrossRef] [PubMed]

3. Matias, I.; Endocannabinoid Research Group; Bisogno, T.; Di Marzo, V. Endogenous cannabinoids in the brain and peripheral tissues: Regulation of their levels and control of food intake. Int. J. Obes. 2006, 30, S7-S12. [CrossRef] 
4. Blankman, J.L.; Simon, G.M.; Cravatt, B.F. A comprehensive profile of brain enzymes that hydrolyze the endocannabinoid 2-arachidonoylglycerol. Chem. Biol. 2007, 14, 1347-1356. [CrossRef] [PubMed]

5. Savinainen, J.R.; Saario, S.M.; Laitinen, J.T. The serine hydrolases MAGL, ABHD6 and ABHD12 as guardians of 2arachidonoylglycerol signalling through cannabinoid receptors. Acta Physiol. 2011, 204, 267-276. [CrossRef]

6. Kinsey, S.G.; Long, J.Z.; O’Neal, S.T.; Abdullah, R.A.; Poklis, J.L.; Boger, D.; Cravatt, B.F.; Lichtman, A.H. Blockade of endocannabinoid-degrading enzymes attenuates neuropathic pain. J. Pharmacol. Exp. Ther. 2009, 330, 902-910. [CrossRef] [PubMed]

7. Kinsey, S.G.; Long, J.Z.; Cravatt, B.F.; Lichtman, A.H. Fatty acid amide hydrolase and monoacylglycerol lipase inhibitors produce anti-allodynic effects in mice through distinct cannabinoid receptor mechanisms. J. Pain 2010, 11, 1420-1428. [CrossRef] [PubMed]

8. Hohmann, A.G.; Suplita, R.L.; Bolton, N.M.; Neely, M.H.; Fegley, D.; Mangieri, R.; Krey, J.F.; Walker, J.M.; Holmes, P.V.; Crystal, J.D.; et al. An endocannabinoid mechanism for stress-induced analgesia. Nat. Cell Biol. 2005, 435, 1108-1112. [CrossRef] [PubMed]

9. Connell, K.; Bolton, N.; Olsen, D.; Piomelli, D.; Hohmann, A.G. Role of the basolateral nucleus of the amygdala in endocannabinoid-mediated stress-induced analgesia. Neurosci. Lett. 2006, 397, 180-184. [CrossRef]

10. Guindon, J.; Guijarro, A.; Piomelli, D.; Hohmann, A.G. Peripheral antinociceptive effects of inhibitors of monoacylglycerol lipase in a rat model of inflammatory pain. Br. J. Pharmacol. 2010, 163, 1464-1478. [CrossRef] [PubMed]

11. Guindon, J.; Lai, Y.; Takacs, S.M.; Bradshaw, H.B.; Hohmann, A.G. Alterations in endocannabinoid tone following chemotherapyinduced peripheral neuropathy: Effects of endocannabinoid deactivation inhibitors targeting fatty-acid amide hydrolase and monoacylglycerol lipase in comparison to reference analgesics following cisplatin treatment. Pharmacol. Res. 2013, 67, 94-109. [PubMed]

12. Aaltonen, N.; Kedzierska, E.; Orzelska-Górka, J.; Lehtonen, M.; Navia-Paldanius, D.; Jakupovic, H.; Savinainen, J.R.; Nevalainen, T.; Laitinen, J.T.; Parkkari, T.; et al. In vivo characterization of the ultrapotent monoacylglycerol lipase inhibitor $\{4$-[bis(benzo[d][1,3]dioxol-5-yl)methyl]-piperidin-1-yl\}(1H-1,2,4-triazol-1-yl)methanone (JJKK-048). J. Pharm. Exp. Ther. 2016, 359, 62-72. [CrossRef] [PubMed]

13. Nomura, D.K.; Lombardi, D.P.; Chang, J.W.; Niessen, S.; Ward, A.M.; Long, J.Z.; Hoover, H.H.; Cravatt, B.F. Monoacylglycerol lipase exerts dual control over endocannabinoid and fatty acid pathways to support prostate cancer. Chem. Biol. 2011, 18, 846-856. [CrossRef]

14. Chen, R.; Zhang, J.; Wu, Y.; Wang, D.; Feng, G.; Tang, Y.-P.; Teng, Z.; Chen, C. Monoacylglycerol lipase is a therapeutic target for Alzheimer's Disease. Cell Rep. 2012, 2, 1329-1339. [CrossRef] [PubMed]

15. McAllister, L.A.; Butler, C.R.; Mente, S.; O’Neil, S.V.; Fonseca, K.R.; Piro, J.R.; Cianfrogna, J.A.; Foley, T.L.; Gilbert, A.M.; Harris, A.R.; et al. Discovery of trifluoromethyl glycol carbamates as potent and selective covalent monoacylglycerol lipase (MAGL) inhibitors for treatment of neuroinflammation. J. Med. Chem. 2018, 61, 3008-3026. [CrossRef] [PubMed]

16. Cisar, J.S.; Weber, O.D.; Clapper, J.R.; Blankman, J.L.; Henry, C.L.; Simon, G.M.; Alexander, J.P.; Jones, T.K.; Ezekowitz, R.A.B.; O'Neill, G.P.; et al. Identification of ABX-1431, a selective inhibitor of monoacylglycerol lipase and clinical candidate for treatment of neurological disorders. J. Med. Chem. 2018, 61, 9062-9084. [CrossRef]

17. Maione, S.; Morera, E.; Marabese, I.; Ligresti, A.; Luongo, L.; Ortar, G.; DiMarzo, V. Antinociceptive effects of tetrazole inhib-itors of endocannabinoid inactivation: Cannabinoid and noncannabinoid receptor-mediated mechanisms. Br. J. Pharmacol. 2008, 155, 775-782. [CrossRef] [PubMed]

18. Fowler, C.J. Monoacylglycerol lipase-A target for drug development? Br. J. Pharmacol. 2012, 166, 1568-1585. [CrossRef] [PubMed]

19. Mulvihill, M.M.; Nomura, D.K. Therapeutic potential of monoacylglycerol lipase inhibitors. Life Sci. 2013, 92, 492-497. [CrossRef] [PubMed]

20. Alhouayek, M.; Masquelier, J.; Muccioli, G.G. Controlling 2-arachidonoylglycerol metabolism as an anti-inflammatory strategy. Drug Discov. Today 2014, 19, 295-304. [CrossRef] [PubMed]

21. Guzman, M. A new age for MAGL. Chem. Biol. 2010, 17, 4-6. [CrossRef]

22. Long, J.Z.; Nomura, D.K.; Cravatt, B.F. Characterization of monoacylglycerol lipase inhibition reveals differences in central and peripheral endocannabinoid metabolism. Chem. Biol. 2009, 16, 744-753. [CrossRef] [PubMed]

23. Lass, A.; Zimmermann, R.; Oberer, M.; Zechner, R. Lipolysis-A highly regulated multi-enzyme complex mediates the catabolism of cellular fat stores. Prog. Lipid Res. 2011, 50, 14-27. [CrossRef]

24. Dorsam, R.T.; Gutkind, J.S. G-protein-coupled receptors and cancer. Nat. Rev. Cancer 2007, 7, 79-94. [CrossRef] [PubMed]

25. Nomura, D.K.; Long, J.Z.; Niessen, S.; Hoover, H.S.; Ng, S.-W.; Cravatt, B.F. Monoacylglycerol lipase regulates a fatty acid network that promotes cancer pathogenesis. Cell 2010, 140, 49-61. [CrossRef]

26. Nomura, D.K.; Morrison, B.E.; Blankman, J.L.; Long, J.Z.; Kinsey, S.G.; Marcondes, M.C.G.; Ward, A.M.; Hahn, Y.K.; Lichtman, A.H.; Conti, B.; et al. Endocannabinoid hydrolysis generates brain prostaglandins that promote neuroinflammation. Science 2011, 334, 809-813. [CrossRef]

27. Ye, L.; Zhang, B.; Seviour, E.G.; Tao, K.-X.; Liu, X.-H.; Ling, Y.; Chen, J.-Y.; Wang, G.-B. Monoacylglycerol lipase (MAGL) knockdown inhibits tumor cells growth in colorectal cancer. Cancer Lett. 2011, 307, 6-17. [CrossRef]

28. King, A.R.; Duranti, A.; Tontini, A.; Rivara, S.; Rosengarth, A.; Clapper, J.R.; Astarita, G.; Geaga, J.A.; Luecke, H.; Mor, M.; et al. URB602 inhibits monoacylglycerol lipase and selectively blocks 2-arachidonoylglycerol degradation in intact brain slices. Chem. Biol. 2007, 14, 1357-1365. [CrossRef] [PubMed] 
29. Muccioli, G.G.; LaBar, G.; Lambert, D.M. CAY10499, a novel monoglyceride lipase inhibitor evidenced by an expeditious MGL assay. ChemBioChem 2008, 9, 2704-2710. [CrossRef] [PubMed]

30. Minkkilä, A.; Savinainen, J.R.; Käsnänen, H.; Xhaard, H.; Nevalainen, T.; Laitinen, J.T.; Poso, A.; Leppänen, J.; Saario, S.M. Screening of various hormone-sensitive lipase inhibitors as endocannabinoid-hydrolyzing enzyme inhibitors. ChemMedChem 2009, 4, 1253-1259. [CrossRef]

31. Long, J.Z.; Jin, X.; Adibekian, A.; Li, W.; Cravatt, B.F. Characterization of tunable piperidine and piperazine carbamates as inhibitors of endocannabinoid hydrolases. J. Med. Chem. 2010, 53, 1830-1842. [CrossRef] [PubMed]

32. Bertrand, T.; Augé, F.; Houtmann, J.; Rak, A.; Vallée, F.; Mikol, V.; Berne, P.; Michot, N.; Cheuret, D.; Hoornaert, C.; et al. Structural basis for human monoglyceride lipase inhibition. J. Mol. Biol. 2010, 396, 663-673. [CrossRef]

33. Chang, J.W.; Niphakis, M.J.; Lum, K.M.; Cognetta, A.B.; Wang, C.; Matthews, M.L.; Niessen, S.; Buczynski, M.W.; Parsons, L.H.; Cravatt, B.F. Remarkably selective inhibitors of monoacylglycerol lipase bearing a reactive group that is bioisosteric with endocannabinoid substrates. Chem. Biol. 2012, 19, 579-588. [CrossRef]

34. Morera, L.; LaBar, G.; Ortar, G.; Lambert, D.M. Development and characterization of endocannabinoid hydrolases FAAH and MAGL inhibitors bearing a benzotriazol-1-yl carboxamide scaffold. Bioorg. Med. Chem. 2012, 20, 6260-6275. [CrossRef]

35. Aaltonen, N.; Savinainen, J.R.; Ribas, C.R.; Rönkkö, J.; Kuusisto, A.; Korhonen, J.; Navia-Paldanius, D.; Häyrinen, J.; Takabe, P.; Käsnänen, H.; et al. Piperazine and piperidine triazole ureas as ultrapotent and highly selective inhibitors of monoacylglycerol lipase. Chem. Biol. 2013, 20, 379-390. [CrossRef]

36. Aida, J.; Fushimi, M.; Kusumoto, T.; Sugiyama, H.; Arimura, N.; Ikeda, S.; Sasaki, M.; Sogabe, S.; Aoyama, K.; Koike, T. Design, synthesis, and evaluation of piperazinyl pyrrolidin-2-ones as a novel series of reversible monoacylglycerol lipase inhibitors. $J$. Med. Chem. 2018, 61, 9205-9217. [CrossRef]

37. Granchi, C.; Lapillo, M.; Glasmacher, S.; Bononi, G.; Licari, C.; Poli, G.; El Boustani, M.; Caligiuri, I.; Rizzolio, F.; Gertsch, J.; et al. Optimization of a benzoylpiperidine class identifies a highly potent and selective reversible monoacylglycerol lipase (MAGL) inhibitor. J. Med. Chem. 2019, 62, 1932-1958. [CrossRef]

38. Castelli, R.; Scalvini, L.; Vacondio, F.; Lodola, A.; Anselmi, M.; Vezzosi, S.; Carmi, C.; Bassi, M.; Ferlenghi, F.; Rivara, S. Benzisothiazolinone derivatives as potent allosteric monoacylglycerol lipase inhibitors that functionally mimic sulfenylation of regulatory cysteines. J. Med. Chem. 2020, 63, 1261-1280. [CrossRef]

39. LaBar, G.; Bauvois, C.; Borel, F.; Ferrer, J.-L.; Wouters, J.; Lambert, D.M. Crystal structure of the human monoacylglycerol lipase, a key actor in endocannabinoid signaling. ChemBioChem 2009, 11, 218-227. [CrossRef]

40. Schalk-Hihi, C.; Schubert, C.; Alexander, R.; Bayoumy, S.; Clemente, J.C.; Deckman, I.; DesJarlais, R.L.; Dzordzorme, K.C.; Flores, C.M.; Grasberger, B.; et al. Crystal structure of a soluble form of human monoglyceride lipase in complex with an inhibitor at 1.35 Å resolution. Protein Sci. 2011, 20, 670-683. [CrossRef]

41. Scalvini, L.; Piomelli, D.; Mor, M. Monoglyceride lipase: Structure and inhibitors. Chem. Phys. Lipids 2016, 197, 13-24. [CrossRef] [PubMed]

42. Afzal, O.; Kumar, S.; Kumar, R.; Firoz, A.; Jaggi, M.; Bawa, S. Docking based virtual screening and molecular dynamics study to identify potential monoacylglycerol lipase inhibitors. Bioorg. Med. Chem. Lett. 2014, 24, 3986-3996. [CrossRef]

43. Afzal, O.; Akhtar, S.; Kumar, S.; Ali, R.; Jaggi, M.; Bawa, S. Hit to lead optimization of a series of N-[4-(1,3-benzothiazol-2yl)phenyl]acetamides as monoacylglycerol lipase inhibitors with potential anticancer activity. Eur. J. Med. Chem. 2016, 121, 318-330. [CrossRef] [PubMed]

44. Ali, M.R.; Kumar, S.; Shalmali, N.; Afzal, O.; Azim, S.; Chanana, D.; Alam, O.; Paudel, Y.N.; Sharma, M.; Bawa, S. Development of thiazole-5-carboxylate derivatives as selective inhibitors of monoacylglycerol lipase as target in cancer. Mini Rev. Med. Chem. 2019, 19, 410-423. [CrossRef]

45. Altamimi, A.S.A.; Bawa, S.; Athar, F.; Hassan, Q.; Riadi, Y.; Afzal, O. Pyrrolidin-2-one linked benzofused heterocycles as novel small molecule monoacylglycerol lipase inhibitors and antinociceptive agents. Chem. Biol. Drug Des. 2020, 96, 1418-1432. [CrossRef]

46. Mickevicius, M.; Beresnevicius, Z.J.; Mickevicius, V.; Mikulskiene, G. Condensation products of 1-aryl-4-carboxy-2-pyrrolidinones with o-diaminoarenes, o-aminophenol, and their structural studies. Heteroat. Chem. 2006, 17, 47-56. [CrossRef]

47. Granchi, C.; Rizzolio, F.; Palazzolo, S.; Carmignani, S.; Macchia, M.; Saccomanni, G.; Manera, C.; Martinelli, A.; Minutolo, F.; Tuccinardi, T. Structural optimization of 4-chlorobenzoylpiperidine derivatives for the development of potent, reversible, and selective monoacylglycerol lipase (MAGL) inhibitors. J. Med. Chem. 2016, 59, 10299-10314. [CrossRef]

48. Mor, M.; Rivara, S.; Lodola, A.; Plazzi, P.V.; Tarzia, G.; Duranti, A.; Tontini, A.; Piersanti, G.; Kathuria, S.; Piomelli, D. Cyclohexylcarbamic acid 3'- or 4'-substituted biphenyl-3-yl esters as fatty acid amide hydrolase inhibitors: Synthesis, quantitative structure-activity relationships, and molecular modeling studies. J. Med. Chem. 2004, 47, 4998-5008. [CrossRef] [PubMed]

49. Ghose, A.K.; Herbertz, T.; Hudkins, R.L.; Dorsey, B.D.; Mallamo, J.P. Knowledge-based, central nervous system (CNS) lead selection and lead optimization for CNS drug discovery. ACS Chem. Neurosci. 2012, 3, 50-68. [CrossRef]

50. Yang, H.; Lou, C.; Sun, L.; Li, J.; Cai, Y.; Wang, Z.; Li, W.; Liu, G.; Tang, Y. admetSAR 2.0: Web-service for prediction and optimization of chemical ADMET properties. Bioinformatics 2018, 35, 1067-1069. [CrossRef]

51. Coderre, T.J.; Vaccarino, A.L.; Melzack, R. Central nervous system plasticity in the tonic pain response to subcutaneous for-malin injection. Brain Res. 1990, 535, 155-158. [CrossRef] 
52. Laughlin, T.M.; Tram, K.V.; Wilcox, G.L.; Birnbaum, A.K. Comparison of antiepileptic drugs tiagabine, lamotrigine, and gabapentin in mouse models of acute, prolonged, and chronic nociception. J. Pharmacol. Exp. Ther. 2002, 302, 1168-1175. [CrossRef] [PubMed]

53. Grever, M.R.; A Schepartz, S.; A Chabner, B. The National Cancer Institute: Cancer drug discovery and development program. Semin. Oncol. 1992, 19, 622-638. [PubMed]

54. Shoemaker, R.H. The NCI60 human tumour cell line anticancer drug screen. Nat. Rev. Cancer 2006, 6, 813-823. [CrossRef] [PubMed]

55. Friesner, R.A.; Murphy, R.B.; Repasky, M.P.; Frye, L.L.; Greenwood, J.R.; Halgren, T.A.; Sanschagrin, P.C.; Mainz, D.T. Extra precision glide: Docking and scoring incorporating a model of hydrophobic enclosure for protein-ligand complexes. J. Med. Chem. 2006, 49, 6177-6196. [CrossRef] 